\title{
A new crustal model of the Anatolia-Aegean domain: evidence for the dominant role of isostasy in the support of the Anatolian plateau
}

\author{
Hayrullah Karabulut, ${ }^{1}$ Anne Paul, ${ }^{2}$ Ali Değer Özbakır, ${ }^{1}$ Tuğçe Ergün ${ }^{1}$ and Selver Şentürk ${ }^{3}$ \\ ${ }^{1}$ Boğaziçi University, Kandilli Observatory and Earthquake Research Institute, Department of Geophysics, 34685 Istanbul, Turkey. E-mail: kara@boun.edu.tr \\ ${ }^{2}$ Univ. Grenoble Alpes, Univ. Savoie Mont Blanc, CNRS, IRD, IFSTTAR, ISTerre, F-38000 Grenoble, France \\ ${ }^{3}$ Eurasian Institute of Earth Sciences, Istanbul Technical University, 34469 Maslak, Istanbul, Turkey
}

Accepted 2019 March 20. Received 2019 February 28; in original form 2018 September 24

\begin{abstract}
SUMMAR Y
The engines of surface deformation in the Anatolia-Aegean region are a matter of debate, including the origin of the high elevations of the Anatolian plateau. Recent publications based on geological and thermomechanical modelling emphasize the role of dynamic topography in the plateau uplift. However, quantitative estimates of the contribution of dynamic topography are affected by large uncertainties due to insufficient knowledge of the crustal structure, in particular crustal thickness and density. To reduce these uncertainties, we provide a new accurate crustal thickness map of the Anatolia-Aegean domain computed from a large volume of broadband seismic data. In addition, we display high-resolution seismic sections of the internal structure of the crust in Western and Central Anatolia. Density contrasts are derived from the same seismic data set and Bouguer gravity anomaly computed from the EGM2008 model. Our crustal thickness model is highly correlated with the topography suggesting that the Anatolian plateau is close to isostatic equilibrium. The average density difference between crust and upper mantle computed from our crustal model and Bouguer gravity anomaly is low compared to the global average, $\sim 0.315 \times 10^{3} \mathrm{~kg} \mathrm{~m}^{-3}$. The ratio of surface elevation to crustal thickness is lower than average, 1/9.4, which also indicates a low-density crust. Differences between isostatic topography and observed topography are overall small $(<500 \mathrm{~m})$. The eastto-west gradients of crustal thickness and topography changes are nearly constant in between the Taurides and Pontides at the northern and southern borders of Anatolia. The observed constant crustal thickness gradient may indicate a low viscosity lower crust supported by the thin mantle lithosphere evidenced by seismic tomography beneath the Anatolian plateau. We propose that viscous flow in the lower crust has smoothed out lateral changes in the crustal structure expected for such a heterogeneous collage of continental fragments. This flow may originate from gravitational potential energy differences between Eastern Anatolia (thick crust, high elevations) and the Aegean Sea (thin crust, low elevations), suggesting that gravity plays an integral part in the westward escape of Anatolia.
\end{abstract}

Key words: Crustal imaging; Seismic tomography; Dynamics: gravity and tectonics; Rheology: crust and lithosphere.

\section{INTRODUCTION}

Plateaus are large-wavelength high-elevation topographical features, which are believed to be supported either by isostatic compensation of density contrasts within the lithosphere or by vertical tractions at the base of the lithosphere due to mantle convection (Molnar et al. 2015). Mantle convection also alters the density variations of the uppermost mantle by advection of buoyancy anomalies. The joint effect of viscous stresses and buoyancy variations on surface elevation is generally referred to as dynamic topography.
Anatolia is an orogenic plateau of Neogene age, located on the upper plate of Eurasia-Africa/Arabia convergence (Dewey et al. 1986). Its eastern part, the East Anatolian High Plateau (EAHP) is believed to be dynamically supported (Şengör et al. 2003; Zor et al. 2003). Recent models predict kilometre-scale dynamic topography of both the EAHP (Gögüş \& Pysklywec 2008; Boschi et al. 2010; Faccenna \& Becker 2010) and the Central Anatolian plateau (Faccenna et al. 2006; Bartol \& Govers 2014). These studies report dynamic topography estimates ranging from 1 to $3 \mathrm{~km}$ for various crustal models and geodynamic scenarios. 
The conundrum of isostatic versus dynamic topography is part of the general discussion on the deformation of Anatolian lithosphere. The engine of deformation of the Anatolia-Aegean domain (AAD) is still debated, in particular the role of mantle convection at regional scale and the related basal tractions, versus the role of gravitational potential energy (GPE) stored within the lithosphere (e.g. Faccenna \& Becker 2010; Özeren \& Holt 2010). Mantle convection is primarily driven by density contrasts below the lithosphere, whereas GPE reflects processes above a compensation depth, usually at the base of the lithosphere (Ranalli 1995). Hence, studying the support of the Anatolian plateau may provide crucial evidence to understand the dynamics of the AAD, and it can also give clues on the dynamics of large-scale belts (e.g. Molnar 1988).

Crustal and mantle processes in the Anatolia-Aegean region either contribute to or counteract buoyancy. Crustal thickening (via mechanisms such as sedimentation, pure shear, crustal flow, nappe stacking, etc.), delamination and/or detachment of mantle lithosphere and underplating of buoyant density anomalies are examples of such processes. Therefore, the response of the crust-mantle boundary to lithospheric or sublithospheric processes affects various observables.

In this study, we provide an accurate crustal thickness map of the AAD computed from a large volume of broadband seismic data. In addition, we display high-resolution seismic sections of the internal structure of the crust in Western Anatolia (WA) and Central Anatolia (CA). We combine seismic observations with gravity anomaly data to constrain the relations between surface topography and crustal thickness, density and normal tractions applied to the base of the lithosphere. Our crustal thickness model is highly correlated with the topography suggesting that the Anatolian plateau is close to isostatic equilibrium. This result differs from other studies that suggest the out-of-equilibrium state of the Anatolian crust/lithosphere (e.g. Şengör et al. 2003; Faccenna \& Becker 2010; Komut et al. 2012). The observed west-to-east constant gradient of topography and crustal thickness suggests that GPE is an important player in the westward motion of Anatolia and in shaping the topography and the crust-mantle interface.

We propose that the thin lithospheric mantle below the Central and Eastern Anatolian plateaus evidenced from previous tomography studies (e.g. Bijwaard et al. 1998; Bijwaard \& Spakman 2000; Piromallo \& Morelli 2003; Salaün et al. 2012; Karabulut et al. 2015; Kind et al. 2015) plays a key role in the thermal-mechanical weakening of the Anatolian crust. Lower crustal flow might be responsible for the smoothing out of the crust-mantle interface, in a similar process as the one proposed for the Tibetan plateau (e.g. Royden et al. 1997; Liu et al. 2014, and references therein).

\subsection{Tectonic setting}

The AAD is located in the convergence zone between the African (Nubian), Arabian and Eurasian plates (McKenzie 1972). Since the late Cretaceous, the subduction of the Neo-Tethys Ocean under the Pontide island arc and the accretion of Gondwana-derived terranes (Menderes Massif, Kırşehir Massif, Tauride platform) to the north at the end of the Eocene, resulted in the formation of the AAD (Şengör \& Yilmaz 1981; Fig. 1). This Eastern Mediterranean subduction resumed during Oligocene times (Şengör \& Y1lmaz 1981; Dercourt et al. 2000; Jolivet et al. 2003; Barrier et al. 2008; Brun \& Faccenna 2008; Ring et al. 2010). Continental collision of African and Arabian plates with Eurasian plate in the early Miocene has led to the formation of land-locked Mediterranean basins, which have controlled the subsequent evolution of the Mediterranean subduction zones. Such land-locked basin settings promote fast subduction rollback and contemporaneous collision, often side-by-side (Jolivet \& Faccenna 2000). After the mid-Miocene (ca. 8-12 Ma), a large-scale topographical inversion occurred within the AAD. The western region ( $c a .2 \mathrm{~km}$ high) collapsed and submerged, ultimately forming the Aegean Sea (Le Pichon et al. 2002; Jolivet et al. 2013). The central and eastern sections uplifted to form the eastern Anatolian high plateau (EAHP) and the central Anatolian plateau (CAP), with average elevations of 2 and $1 \mathrm{~km}$, respectively (Şengör et al. 2008; Cosentino et al. 2012; Schildgen et al. 2014). Volcanism developed and intensified from the beginning of the Miocene in both EAHP and CAP (Ercan 1985; Pasquare et al. 1988; Toprak \& Göncöoğlu 1993; Keskin 2003).

Synchronously with these vertical motions, the North Anatolian Fault (NAF) developed on the pre-existing Izmir-Ankara-Erzincan Suture (IAES) during Serravalian times (age constrained from the oldest basins along the NAF) and propagated to the west (Şengör et al. 2005). The East Anatolian Fault (EAF) initiated during the (mid-)Pliocene (Şaroğlu 1985; Şaroğlu et al. 1992; Westaway 1994, 2004; Hubert-Ferrari et al. 2007, 2009) due to the evolution of the triple junction between Anatolia, Africa and Arabia. After the formation of the NAF and the EAF, and adequate build-up of topography since the mid-Miocene, north-south convergence at the Eurasia-Africa/Arabia Plate margin transformed into predominantly $\mathrm{E}-\mathrm{W}$ relative motions.

In brief, the $\mathrm{AAD}$ is characterized by a transient tectonic setting, where three major plate reorganizations occurred after the formation of: (1) the Early Miocene Bitlis-Zagros collision while subduction was ongoing at the Hellenic trench and extension in the Aegean domain, (2) the Middle Miocene initiation of the NAF and the uplift of both central and east Anatolia and (3) Late Miocene-Pliocene intensification of the deformation, with the initiation of EAF and westward extrusion of Anatolia (Allen et al. 2004). Across length scales of $c a .2000 \mathrm{~km}$, these changes are believed to be governed by a common deformational mechanism (McClusky et al. 2000; Faccenna et al. 2006).

\subsection{Lithospheric structure}

Regional plate boundaries are well defined: the North Anatolian Fault (NAF) accommodates the motion of Anatolia relative to Eurasia, while the East Anatolian Fault (EAF) accommodates the motion of Anatolia relative to Arabia (McKenzie 1976). The plate boundary between the Nubian plate and the AAD follows the HellenicCyprus Trench and the Bitlis/Zagros collision zone (Özbakır et al. 2017). The earthquake map of supplementary Fig. S1 shows that most earthquakes of the AAD are confined in the upper crust. The seismicity clusters along the NAF, the EAF and east-west trending grabens in Western Anatolia. In the Western Cyprus and Hellenic arcs, the distribution of earthquake hypocentres outlines a WadatiBenioff zone reaching depths of 110 and $180 \mathrm{~km}$, respectively while there is no indication of a Benioff zone in the eastern Cyprus arc. The Cyprus arc has a much lower seismicity rate than the Hellenic arc. This is consistent with the convergence rate across the Hellenic Arc $\left(\sim 35 \mathrm{~mm} \mathrm{yr}^{-1}\right)$ being about three times faster than across the Cyprus Arc (Reilinger et al. 2006).

Existing global or continent-scale crustal thickness models have been compiled from various data (CRUST2.0: Bassin et al. 2000; CRUST1.0: Laske et al. 2013; EUcrust: Tesauro et al. 2008) while 


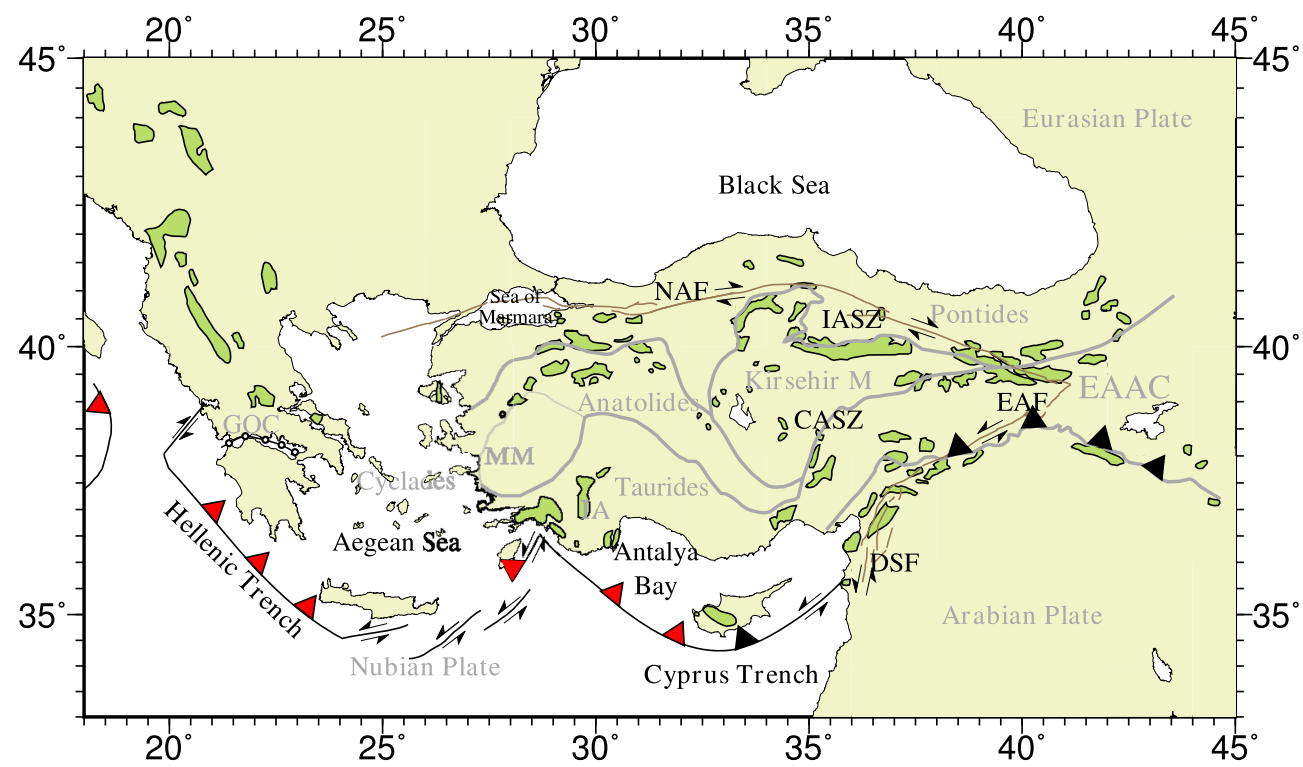

Figure 1. Present-day tectonic setting of the study region (after Okay \& Tüysüz 1999). Red triangles show subduction zones directed towards the overriding plate. Black triangles indicate areas of continental collision. Dark green patches are ophiolites (Mann \& Taira 2004). CASZ, Central Anatolian Shear Zone; DSF, Dead Sea Fault; EAAC, East Anatolian Accretionary Complex; EAF, East Anatolian Fault; GOC, Gulf of Corinth; IASZ, İzmir Ankara suture zone; MM, Menderes Massif; NAF, North Anatolian Fault.

regional ones have been computed from higher quality datasets based on receiver function analysis (Tezel et al. 2013; Vanacore et al. 2013; Vinnik et al 2014; Abgarmi et al. 2017) and Pn residuals (Mutlu \& Karabulut 2011). Gravity modelling provided geometries of the crust-mantle boundaries for the Aegean Sea (Tirel et al. 2004), and the Black Sea (Starostenko et al. 2004; Yegorova et al. 2013). However, the resolution of these data is limited due to the limited spatial coverage and high uncertainties on estimated crustal thickness. A number of previous seismic studies have provided images of the lithosphere and subduction zones in the AAD. These include surface wave dispersion studies (Bakırc1 et al. 2012; Salaün et al. 2012; Delph et al. 2015), receiver-function analyses (Zor et al. 2003; Karabulut et al. 2013; Vanacore et al. 2013; Kind et al. 2015; Abgarmi et al. 2017), Pn tomography (Mutlu \& Karabulut 2011), seismic anisotropy measurements (Paul et al. 2014), full waveform tomography (Fichtner et al. 2013) and traveltime tomography (Spakman et al. 1993; Bijwaard \& Spakman 2000; Piromallo \& Morelli 2003; Biryol et al. 2011).

The teleseismic $P$-wave tomography by Biryol et al. (2011) displays fast wave speed anomalies beneath Anatolia that dip steeply and extend to the mantle transition zone at $660 \mathrm{~km}$. Low velocity anomalies extend from central Anatolia (east of Cyprus) to eastern Anatolia reaching $400 \mathrm{~km}$ depth. The surface wave tomography of Salaün et al. (2012) shows an overall low-velocity zone (80-200 km depth) beneath Anatolia indicating warm asthenosphere underlying a thin mantle lithosphere, mainly within the Tauride unit. The shear wave velocity-depth profiles also show $S$-wave velocities lower than AK135 model all over Anatolia (Salaün et al. 2012). The mantle tomographic models suggest that the mantle lithosphere is replaced by asthenospheric material in a number of places under Anatolia. Subducted slabs reach the mantle transition zone in the west beneath the Aegean Sea (Bijwaard et al. 1998), but they appear segmented at shallower levels, with slab windows below Western Anatolia, the North Aegean Sea and along the Central Anatolian Shear Zone. Such a thin lithospheric mantle presumably plays a key role in weakening the Anatolian crust by thermo-mechanical processes.

\section{CRUSTAL THICKNESS ESTIMATES}

\subsection{Data and methods}

Crustal thicknesses were estimated using receiver function analysis on a large set of seismic data recorded in and around the AAD. We used standard methods that are extensively described in Supplementary Material S2 and Fig. S2.

We selected three-component records of broadband seismic stations in Turkey and surrounding regions (see locations in Fig. 2a). The database contains records from 460 stations of permanent and temporary arrays that operated between 1999 and 2015. The stations were installed by various agencies and through different international projects. The temporary deployments provided at least $1 \mathrm{yr}$ of continuous data while data from permanent stations are available for longer durations (2-10 yr).

The crustal thicknesses were estimated from $H-k$ analysis (Zhu $\&$ Kanamori 2000) and 1-D inversion of receiver functions at 460 stations (see Supplementary Material S2). The majority of stations are located in Turkey (400 stations), while 60 are located in surrounding countries (Greece, Bulgaria and Romania). Spatial coverage is good ( $<\sim 40 \mathrm{~km}$ interstation distance) for stations in Turkey, the Aegean Sea and mainland Greece, providing reliable estimates of crustal thickness variations. The coverage is poor in the Mediterranean Sea, Arabian platform and Caucasus region. Uncertainties estimated from $H-k$ analysis vary between 2 and $4 \mathrm{~km}$.

To fill-in the gap in the Black Sea, we included the crustal thicknesses estimated by Starostenko et al. (2004) and Yegorova et al. (2013) from the modelling of gravity data. Receiver function estimates of crustal thicknesses in Iran (Taghizadeh-Farahmand et al. 2015) and Iraq (Gök et al. 2008) were also used. The point-wise estimates of the crustal thickness were interpolated for a crustal thickness map (Fig. 2b) using a Variogram-Krigging algorithm (Chu 2000). 

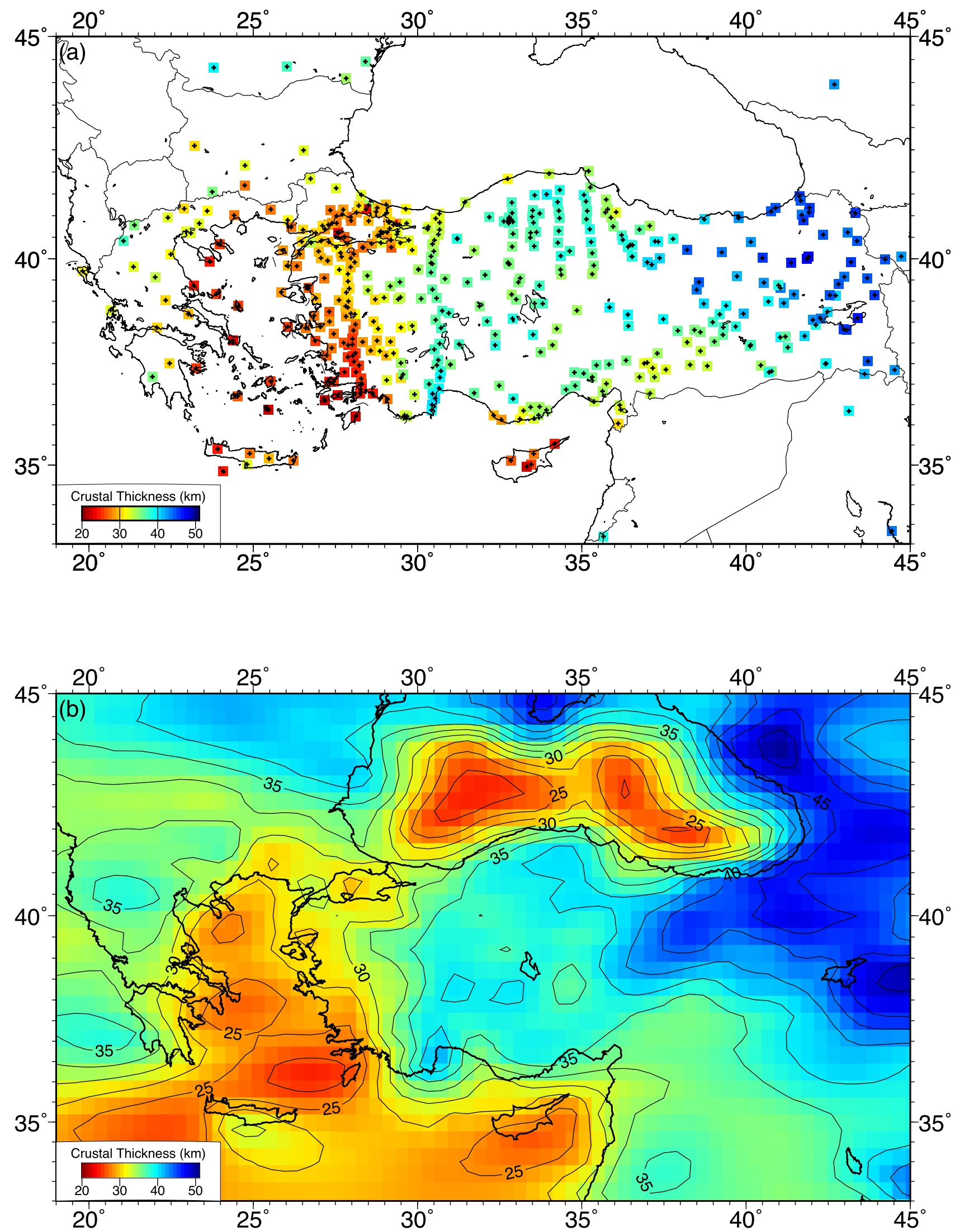

Figure 2. (a) Map of the seismic stations used in this study. The colours indicate the crustal thicknesses estimated from receiver function analysis. (b) Crustal thickness map interpolated from the receiver function measurements at stations shown in Fig. 2a. The crustal thickness estimates for the Black Sea (Starostenko et al. 2004; Yegorova et al. 2013) were included prior to interpolation. Areas of thick crust ( $>40 \mathrm{~km})$ are shown as blue colour, while red colours indicate thin crust $(<25 \mathrm{~km})$. 


\subsection{Crustal thickness variations}

Fig. 2(b) shows that large variations of crustal thickness (20-47 km) are observed from western Greece to eastern Anatolia with large gradients from continental to oceanic regions (in the Black Sea and Mediterranean Sea). However, the crustal thickness variations are rather uniform with gentle gradients within each region, namely Central Anatolia (CA), Eastern Anatolia (EA), Western Anatolia (WA), Aegean Sea and Arabian platform. High topography and large crustal thicknesses in Eastern Anatolia ( $>45 \mathrm{~km}$ ) generally overlap with the accretionary prism bounded to the south by the relatively thinner crust of the Arabian platform (35-37 km). In the Western AAD, crustal thicknesses are $25-30 \mathrm{~km}$, increasing slightly to the north. The central Anatolian plateau appears as a broad transition zone between the thin crust of WA and the thicker crust of EA. The thicknesses decrease gradually from east to west, from $\sim 40$ to $\sim 35 \mathrm{~km}$. The major tectonic boundary between Anatolides and Pontides (along the NAF) does not show any significant crustal thickness contrast, but a trend of crustal thinning is observed towards the Black Sea coast. Crustal thicknesses in the Black Sea sharply drop to 19 and $22 \mathrm{~km}$ in the eastern and western Black Sea basins.

In the south of Anatolia, thicknesses decrease from $\sim 35$ to $\sim 25 \mathrm{~km}$ in the Mediterranean Sea, with the exception of the north of Antalya Bay, where the thickness locally reaches $\sim 40 \mathrm{~km}$. In the west, the crust is locally thinner, that is $\sim 25 \mathrm{~km}$ in the Marmara Sea and $\sim 24 \mathrm{~km}$ in the Cyclades. However, due the scarcity of seismic stations in the Southern Aegean Sea, the interpolation might have caused larger uncertainties for the local minima of crustal thicknesses in the southern Aegean.

In summary, the broad AAD is surrounded by the thin crusts $(<30 \mathrm{~km})$ of the Mediterranean, Aegean and Black Seas, while in Anatolia, crustal thicknesses increase from west to east from $\sim 35 \mathrm{~km}$ at approximately $30^{\circ} \mathrm{E}$ longitude, to $45-47 \mathrm{~km}$ in EA with a gradual increase across CA.

\subsection{Internal structure of the crust along two north-south profiles in WA and CA}

In addition to the crustal thickness map, we present in Fig. 3 two high resolution depth sections of the lithosphere beneath two linear receiver arrays along longitudes $28^{\circ} \mathrm{E}$ and $30.5^{\circ} \mathrm{E}$. The two profiles $200 \mathrm{~km}$ apart were installed during the SIMBAAD project and each was operated for $1 \mathrm{yr}$ (see station location in Fig. 2a; Salaün et al. 2012). We used the common conversion point (CCP) method to migrate the $P$-to- $S$ converted phases to their approximate position at depth (Zhu 2000). We refer to supplementary material S2 for details and to Karabulut et al. (2013) and references therein. Fig. 3 compares the depth-migrated receiver function sections along the $30.5^{\circ} \mathrm{E}$ and $28^{\circ} \mathrm{E}$ profiles. The average receiver spacing along both profiles is $\sim 15 \mathrm{~km}$ providing a high-resolution image of the crustmantle boundary with the strength of Moho reflectivity and some details on the internal structure of the crust.

In the eastern profile at $30.5^{\circ} \mathrm{E}$ (Fig. 3a), the Moho is observed as a laterally continuous strip of positive amplitude between 35 and $43 \mathrm{~km}$ depth, with an average depth of $\sim 37 \mathrm{~km}$. The Moho depth smoothly increases from $41.2^{\circ} \mathrm{N}$ to $38.5^{\circ} \mathrm{N}$ reaching $\sim 37 \mathrm{~km}$ beneath the Anatolian plateau. Beneath Isparta Angle at $\sim 38.5^{\circ} \mathrm{N}$, the Moho is shallower $(\sim 35 \mathrm{~km})$. The crust-mantle boundary has a complicated shape to the south of the Isparta angle where a local thinning is followed by a steep increase. The crustal thickness attains its maximum value of $\sim 42 \mathrm{~km}$ at the southern end of the profile above the subduction zone. The amplitude of the Moho converted phase is strong and shows no significant variation between $41.2^{\circ} \mathrm{N}$ and $38^{\circ} \mathrm{N}$ but it weakens south of the Isparta Angle.

The western profile ( $28^{\circ} \mathrm{E}$; Fig. $\left.3 \mathrm{~b}\right)$ is discussed in Karabulut et al. (2013). Western Anatolia has a thin crust, from $\sim 25 \mathrm{~km}$ beneath the Sea of Marmara and the Menderes Massif to $\sim 22 \mathrm{~km}$ beneath the Mediterranean coast. The Moho beneath the metamorphic core complexes of the Menderes Massif is locally flat and displays longwavelength undulations with depth differences of 6-7 km in 150-km horizontal distance from the two Moho highs of the Marmara Sea and the Menderes Massif to the Moho low beneath the İzmir-Ankara suture zone.

We observe relatively weak mid-crustal conversions on the eastern profile at $15-20 \mathrm{~km}$ depths from the Black Sea coast to the Isparta angle (Fig. 3a). On the western profile, there is no apparent mid or lower crust discontinuity, and only the shallow uppermost crust contributes to the observed converted energy above the crustmantle boundary (see Fig. 5b in Karabulut et al. 2013).

\section{CORRELATIONS BETWEEN CRUSTAL THICKNESS, TOPOGRAPHY AND GRAVITY ANOMALIES}

In this section, we investigate the isostatic state of the AAD and its implications for the residual topography of the Anatolian plateau. Our new crustal model derived from a dense seismic network gives us confidence on the accuracy of our calculations. However, we need reliable estimates of crustal and upper mantle densities to check the isostasy status and discuss the role of the mantle in supporting high elevations. Therefore, we analyse available seismic data and seismic velocity-density relations to derive reasonable density estimates.

\subsection{Crustal thickness vs topography}

First, we explore correlations between topography and crustal thickness using the GTOPO30 digital elevation model with short wavelength variations filtered $(<\sim 100 \mathrm{~km})$. Fig. 4 documents a linear relationship between elevation and crustal thickness: $h=(T-26) / 9.4$, where $h$ is elevation (in $\mathrm{km}$ ) and $T$ crustal thickness (in $\mathrm{km}$ ), with high correlation coefficient $\left(R^{2}=0.82\right)$. This strong correlation between crustal thickness and elevation suggests that the contribution of mantle buoyancy to surface elevation may be negligible. Furthermore, the high ratio (9.4) is likely an evidence for low density difference between crust and upper mantle. Fig. 5 displays comparisons between crustal thickness and topography changes along $\mathrm{W}-\mathrm{E}$ profiles across the AAD. Crustal thickness and topography curves are scaled using the linear relation derived from Fig. 4. Topography clearly correlates with crustal thickness for the three profiles across the Anatolian plateau between $37^{\circ} \mathrm{N}$ and $40^{\circ} \mathrm{N}$, with a regular linear increase from $\mathrm{W}$ to $\mathrm{E}$. However, the correlation and trend break down for the northernmost (Pontides) and southernmost (Taurides) profiles.

\subsection{Crustal thickness versus Bouguer anomaly}

A second observation is the correlation between crustal thickness and Bouguer gravity anomaly. As the Bouguer gravity anomaly is free of topographic effect, it is mostly related to mass excess or deficit below the observation point (i.e. crustal thickness and density anomalies at crustal and mantle depths). The free air anomaly was computed from EGM2008 model (Pavlis et al. 2012). A Bouguer 

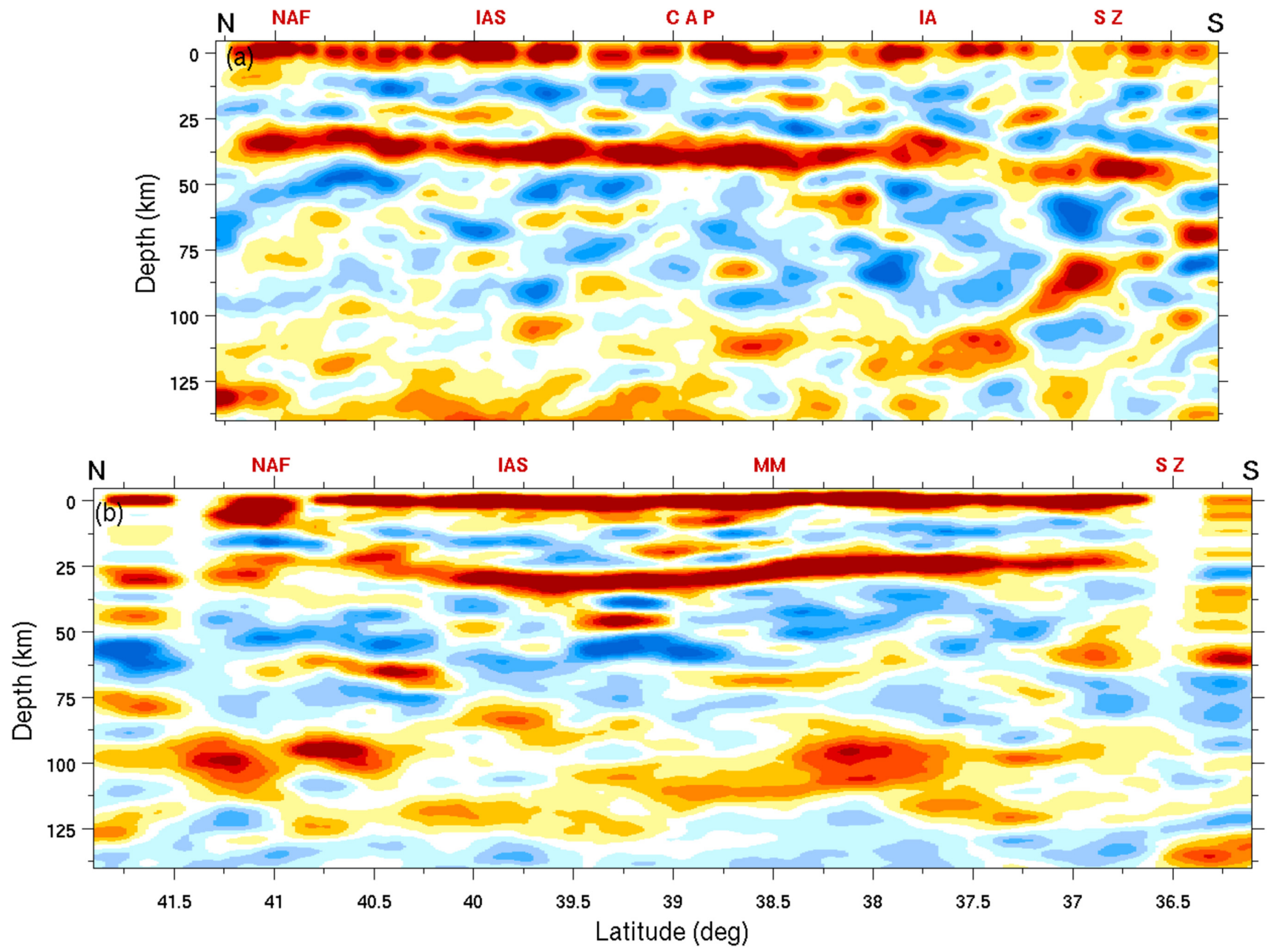

Figure 3. Migrated depth sections of radial receiver function records along two north-south profiles in Western Anatolia. (a) Eastern profile at longitude $30.5^{\circ} \mathrm{E}$ (b) Western profile at longitude $28^{\circ} \mathrm{E}$. No vertical exaggeration. CAP, Central Anatolian Plateau; IA, Isparta Angle; SZ, Subduction Zone; IAS, Izmir-Ankara Suture; MM, Menderes Massif; NAF, North-Anatolian Fault.

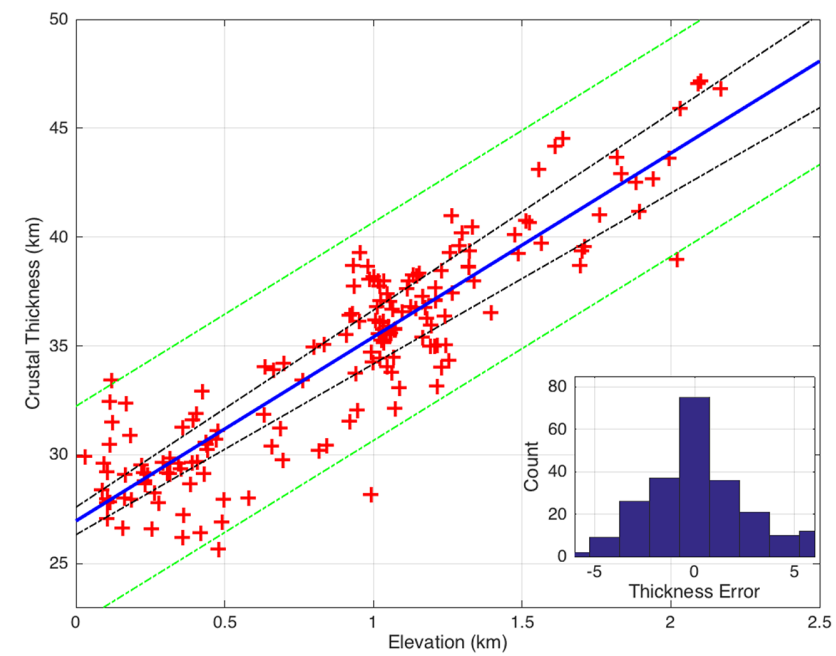

Figure 4. Crustal thickness versus topography sampled at station locations shown in Fig. 2(a) between $37^{\circ} \mathrm{N}-41^{\circ} \mathrm{N}$ and $27^{\circ} \mathrm{E}-42^{\circ} \mathrm{E}$. The thick blue line is $h=(\mathrm{T}-26) / 9.4 . R^{2}$ is estimated as 0.82 . The thin dashed black lines indicate 95 per cent confidence intervals of the blue line while the green dashed lines indicate 95 per cent prediction intervals. Inset figure shows the distribution of crustal thickness deviations from the regression. correction assuming plateau density of $2.67 \times 10^{3} \mathrm{~kg} \mathrm{~m}^{-3}$ was applied on land using DEM and we used free air anomalies at sea (see Fullea et al. 2008, for Bouguer correction). The resulting Bouguer anomaly map shown in Fig. 6(a) is almost a mirror image of the crustal thickness map of Fig. 2(b), particularly in Anatolia where crustal thicknesses calculated from receiver functions are best resolved. Fig. 6(b) shows the correlation between Bouguer anomaly and crustal thicknesses sampled at the same receiver sites: negative Bouguer anomaly values correlate with large crustal thicknesses and vice versa. The correlation in Fig. 6(b) proves that a nearly constant density difference between crust and uppermost mantle in the entire AAD well explains the observations. Using the linear relationship that gives the Bouguer anomaly $\Delta \mathrm{g}$ produced by a slab with thickness $\mathrm{h}$ and density contrast $\Delta \rho(\Delta \mathrm{g}=2 \pi \Delta \rho \mathrm{hG}$, where $G$ is gravitational constant and h is taken as $35 \mathrm{~km}$ ) gives a density difference between crust and mantle of $\sim 0.315 \times 10^{3} \mathrm{~kg} \mathrm{~m}^{-3}$.

\subsection{Crustal density variations}

A homogeneous density difference between crust and uppermost mantle over the entire AAD is questionable as we know from seismic tomography that seismic wave velocities undergo significant 

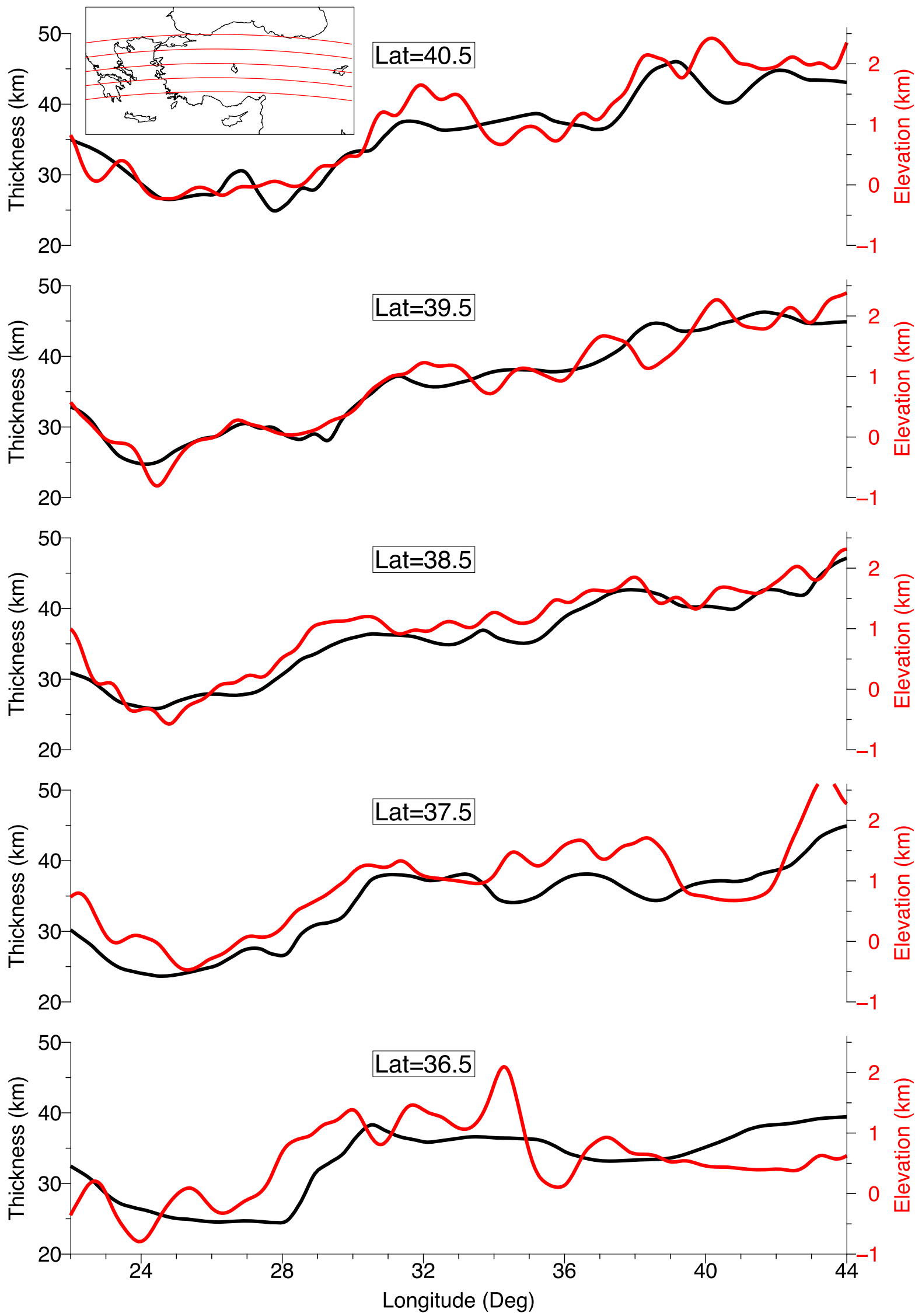

Figure 5. West-east variations of crustal thickness (in black) and topography (in red) at latitudes from north (top panel) to south (bottom panel) across the AAD (see map in inset). 

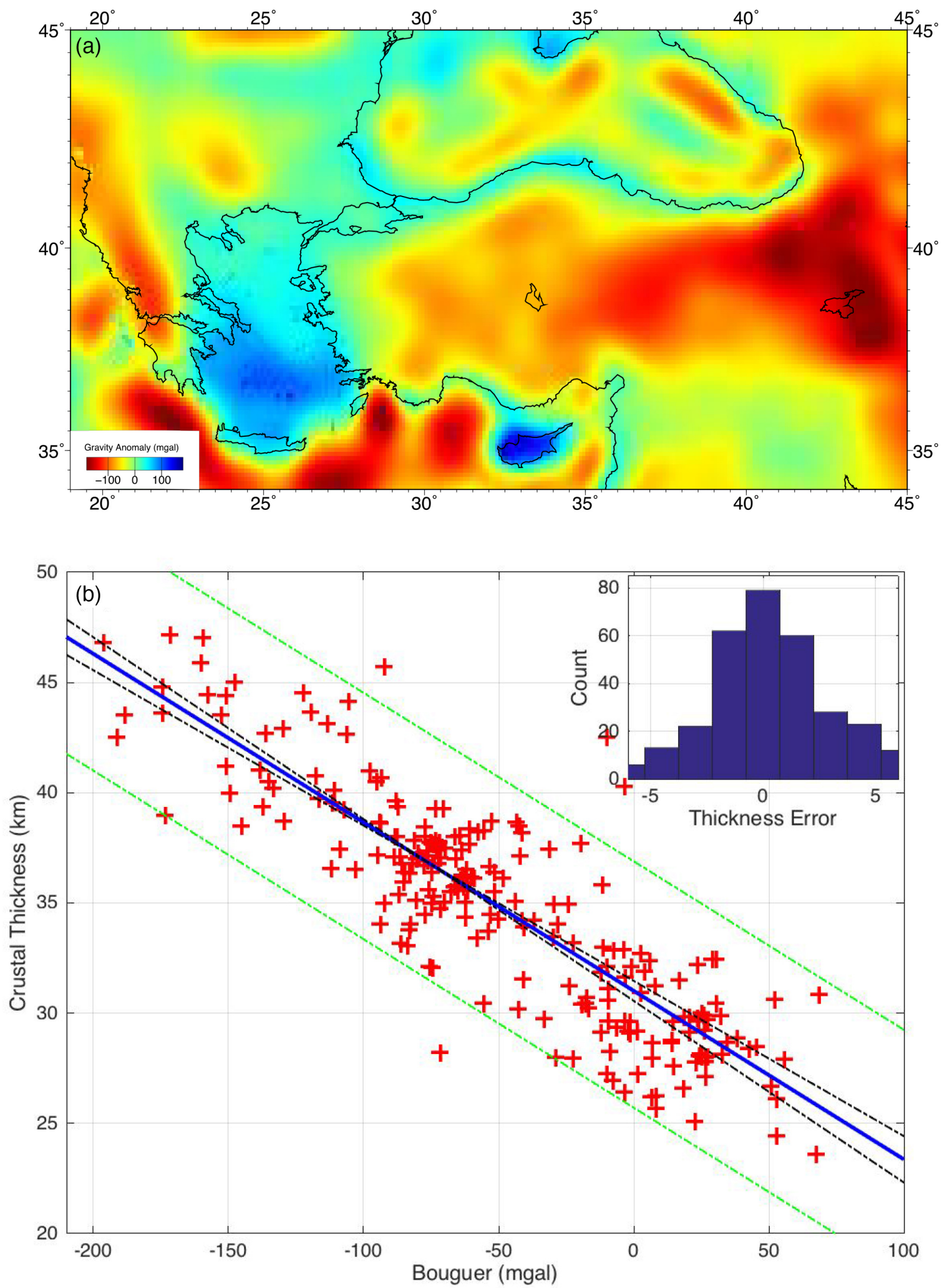

Figure 6. (a) Gravity field of the Anatolia-Aegean domain and surrounding regions: free air anomalies offshore and Bouguer anomalies onshore. Bouguer correction is applied with a density of $2.67 \times 10^{3} \mathrm{~kg} \mathrm{~m}^{-3}$. (b) Crustal thickness versus Bouguer gravity sampled at station locations shown in Fig. 2(a) between $37^{\circ} \mathrm{N}-41^{\circ} \mathrm{N}$ and $27^{\circ} \mathrm{E}-42^{\circ} \mathrm{E}$. The blue thick line is $\mathrm{g}(\mathrm{mgal})=[\mathrm{T}(\mathrm{km})-30] / 0.081 . R^{2}$ is estimated as 0.72 . Thin dashed black lines indicate 95 per cent confidence intervals of the blue line and green dashed lines indicate 95 per cent prediction intervals. Inset figure shows the histogram of crustal thickness departures from the linear regression. 
lateral and vertical variations both in the crust and in the uppermost mantle below Anatolia (e.g. Mutlu \& Karabulut 2011; Delph et al. 2015; Karabulut et al. 2015). In this subsection, we estimate average crustal densities in a three-step process: (1) we map the lateral changes in density contrast at Moho using Bouguer anomaly data and our crustal thickness model; (2) we convert the Pn velocity model of Mutlu \& Karabulut (2011) to a density model of the uppermost mantle assuming a linear relation between $P$-wave velocity and density and (3) the average crustal density model is obtained by subtracting the density change at crust-mantle boundary from the density of the uppermost mantle.

In the first step, we discretized the crustal thickness map in $30 \times 30 \mathrm{~km}^{2}$ cells and inverted for the density contrast at Moho by minimizing the misfit between observed and computed Bouguer anomalies. The details of the inversion are given in Supplementary Material S3. Fig. 7(a) shows the result of the inversion. The crust-mantle density contrast over the AAD is low $\left(<\sim 0.35 \times 10^{3} \mathrm{~kg} \mathrm{~m}^{-3}\right)$ as compared for example to $0.440 \times 10^{3} \mathrm{~kg} \mathrm{~m}^{-3}$ in the reference earth model AK135 (Kennett et al. 1995) or $0.480 \times 10^{3} \mathrm{~kg} \mathrm{~m}^{-3}$ in the global average computed by Tenzer et al. (2012). Fig. 7(b) shows the histogram of density contrasts sampled at the receiver sites where the crustal thicknesses were computed (Fig. 2b). The mean density contrast $\left(0.320 \times 10^{3} \mathrm{~kg} \mathrm{~m}^{-3}\right)$ is close to the value obtained from the linear regression in Fig. 6(b). The low standard deviation $\left(<0.1 \times 10^{3} \mathrm{~kg} \mathrm{~m}^{-3}\right)$ indicates rather homogeneous density differences between crust and uppermost mantle all over AAD.

In the second step, we estimated the density variations in the uppermost mantle using the Pn velocity map of Mutlu \& Karabulut (2011) and assuming a linear relation between velocity and density. A variety of velocity-density relations have been proposed (e.g. Nafe \& Drake 1957; Birch 1961), with many of them of the form $\rho=a+b V p$. Various values of coefficients $\mathrm{a}$ and $\mathrm{b}$ are proposed for different regions. We selected four velocity-density relations computed by Romanyuk et al. (2007) for three different regions in southern California based on the inversion of gravity anomalies along regional transects and a more general one proposed by Ludwig et al. (1971). They are shown in Fig. S4, which documents that the differences between the relations lead to a rather small density difference of $\sim 50 \mathrm{~kg} \mathrm{~m}^{-3}$ for Pn velocity in the range $7.5-8.5 \mathrm{~km} \mathrm{~s}^{-1}$. In the absence of additional constraints, we used the relation proposed by Ludwig et al. (1971).

The Pn velocity model of Mutlu \& Karabulut (2011) shown in Fig. S5(a) displays large deviations $\left( \pm 0.4 \mathrm{~km} \mathrm{~s}^{-1}\right)$ from the average $7.8 \mathrm{~km} \mathrm{~s}^{-1}$. The lowest Pn velocities are observed beneath Anatolia $\left(\sim 7.4 \mathrm{~km} \mathrm{~s}^{-1}\right)$ while high Pn values are observed beneath the Black Sea, the Aegean Sea, the Mediterranean Sea and the Arabian platform $\left(\sim 8.2 \mathrm{~km} \mathrm{~s}^{-1}\right)$. The density distribution computed from Pn velocities is shown in Fig. S5(b). Finally, the crustal densities shown in Fig. 7(c) are obtained by adding the upper mantle densities to the computed density difference between crust and mantle. Low crustal densities are observed over the AAD, with the lowest values in Western and Eastern Anatolia $\left(<2.8 \times 10^{3} \mathrm{~kg} \mathrm{~m}^{-3}\right)$. Higher crustal densities are obtained in the Aegean Sea, north-central Anatolia, Pontides and Arabian platform $\left(>2.8 \times 10^{3} \mathrm{~kg} \mathrm{~m}^{-3}\right)$. Overall, the AAD displays weak lateral changes in average crustal density. The absence of correlation between crustal densities and crustal thicknesses (Fig. 2b), in contrast with global observations by Zoback \& Mooney (2003) indicates that Anatolia deviates from the global behaviour as far as isostasy is concerned.

\section{ISOSTATIC CRUSTAL MODELS}

In this section, we present isostatic models based on the models of crustal thickness and crustal density obtained in Sections 2 and 3.

We first computed crustal thickness maps based on constant density (Airy-Heiskanen) and variable density (Airy-Woollard) models of isostasy using the topography and density values derived in the previous section. Fig. 8(a) shows the crustal thickness map computed from topography assuming the Airy-Heiskanen model with a compensation depth of $45 \mathrm{~km}$ and a constant density contrast between crust and mantle $\left(0.315 \times 10^{3} \mathrm{~kg} \mathrm{~m}^{-3}\right)$. The general trends of this map are similar to those of the crustal thickness map of Fig. 2(b) derived from receiver function analysis. The differences between observed and predicted crustal thickness vary by $\pm 2.5 \mathrm{~km}$ over the AAD. This value is in the range of uncertainties on crustal thickness estimates with receiver functions. The large differences outside AAD indicate significant errors on crustal thickness and/or density estimates. In the AAD, the largest differences in thickness are observed along the Pontides and Taurides (Fig. 8b). As documented by Fig. 5 and outlined in Section 3.1, both regions display anomalous behaviour in the correlations between topography and crustal thickness. Finally, we computed residual topography defined as topography corrected for isostatic adjustment using our crustal thickness and density model (Fig. 8c). The largest negative residuals $(-0.5$ to $-1.0 \mathrm{~km})$ are observed in the Aegean Sea and Western Anatolia while we find slightly positive residuals in eastern Anatolia $(+0.5 \mathrm{~km})$ and overall weak residuals in central Anatolia $( \pm 0.25 \mathrm{~km})$.

We emphasize that the residual topography displayed in Fig. 8(c) cannot be solely interpreted as resulting from unaccounted tectonic forces (that may produce dynamic topography), but they can also be explained by uncertainties in crustal thickness and density estimates. In general, the uncertainties in crustal thickness estimates displayed in Fig. 2 are greater than $2 \mathrm{~km}$, which may lead to $>\sim 200 \mathrm{~m}$ uncertainties in the estimated residual topography. The influence of the crustal density variations on isostasy is investigated in Figs 8(e)-(h) following the variable crustal density variety of Airy isostatic theory introduced by Woollard $(1962,1970)$ and modified by Wilcox (1976), thereafter referred to as the Airy-Woollard isostasy model. The major features of the resulting maps (Figs 8d-f) are similar to the map derived from Airy-Heiskanen model (Fig. 8a). Large thickness differences ( $>5 \mathrm{~km}$ ) are observed along Pontides and Taurides. The patterns of the residual topography maps are different for the Airy-Heiskanen model (Fig. 8c) and Airy-Woollard (Fig. 8g) models. However, the spatial distribution of the residuals is almost random (Figs 8d and h). Fig. 9 shows the histograms of residual topography computed from the two isostatic models. Both models display similar distributions and most residuals are within the $[-0.5 \mathrm{~km} ; 0.5 \mathrm{~km}]$ range.

Studies using global reference crustal models such as CRUST1.0 (Laske et al. 2013) result in residual topography estimates as large as $1500 \mathrm{~m}$. We computed residual topography using CRUST1.0 with two density contrasts between crust and upper mantle, 0.315 and $0.5510^{3} \mathrm{~kg} \mathrm{~m}^{3}$ (see residual topography maps in Fig. S6). The histograms of residual topography are shown in Fig. 10. The residual topography is negative almost everywhere in the AAD for both values of density contrast, and it varies over a wider range $(-1.5$ to $0.5 \mathrm{~km}$ ) than residual topography computed in our crustal thickness model (Fig. 9). The distributions of residuals deviate significantly from the Gaussian shape of histograms in Fig. 9. As expected, larger residual topography is observed for stronger density contrast. Any error in density contrast leads to overestimated residual topography. 

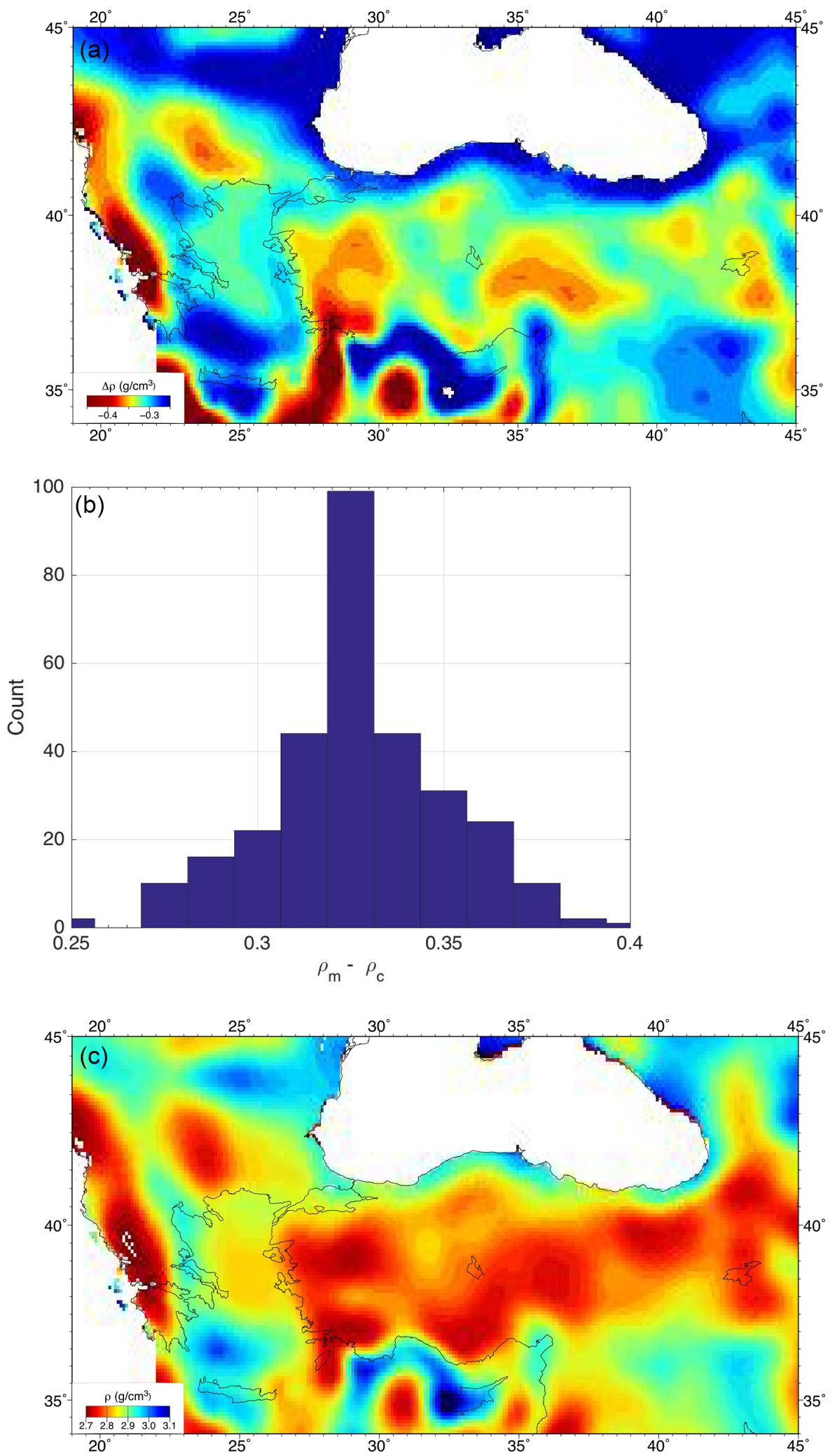

Figure 7. (a) Density difference between crust and mantle computed from the crustal model in Fig. 2(b) and Bouguer anomaly map in Fig. 6(a). (b) Histogram of the density differences between crust and mantle at the same receiver locations as in Fig. 2(a). (c) Crustal density distribution computed from the uppermost mantle density distribution estimated from Pn velocities and density difference between crust and uppermost mantle shown in Fig. 7(a). The white areas are clipped. 


\section{Airy-Heiskanen}
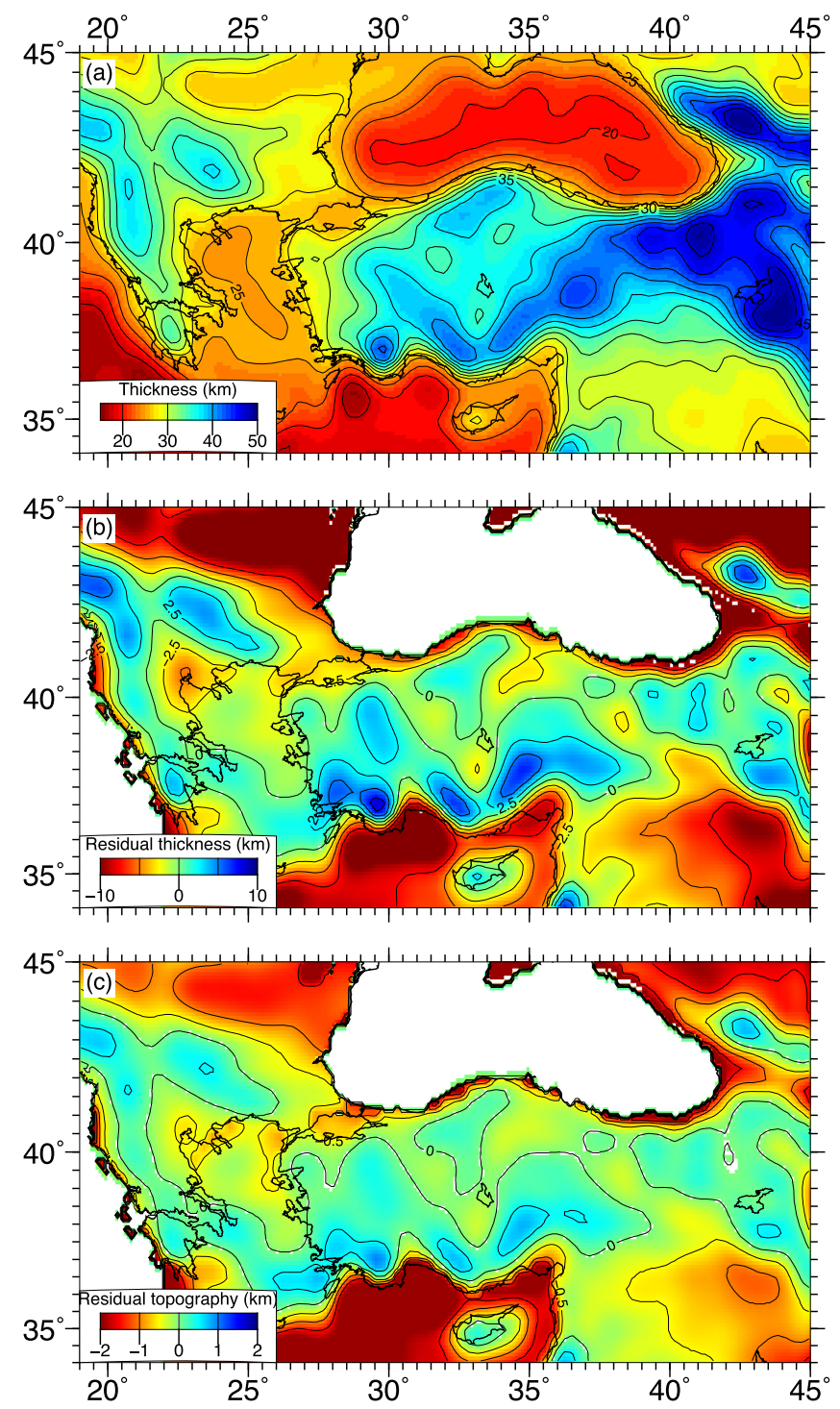

\section{Airy-Woollard}
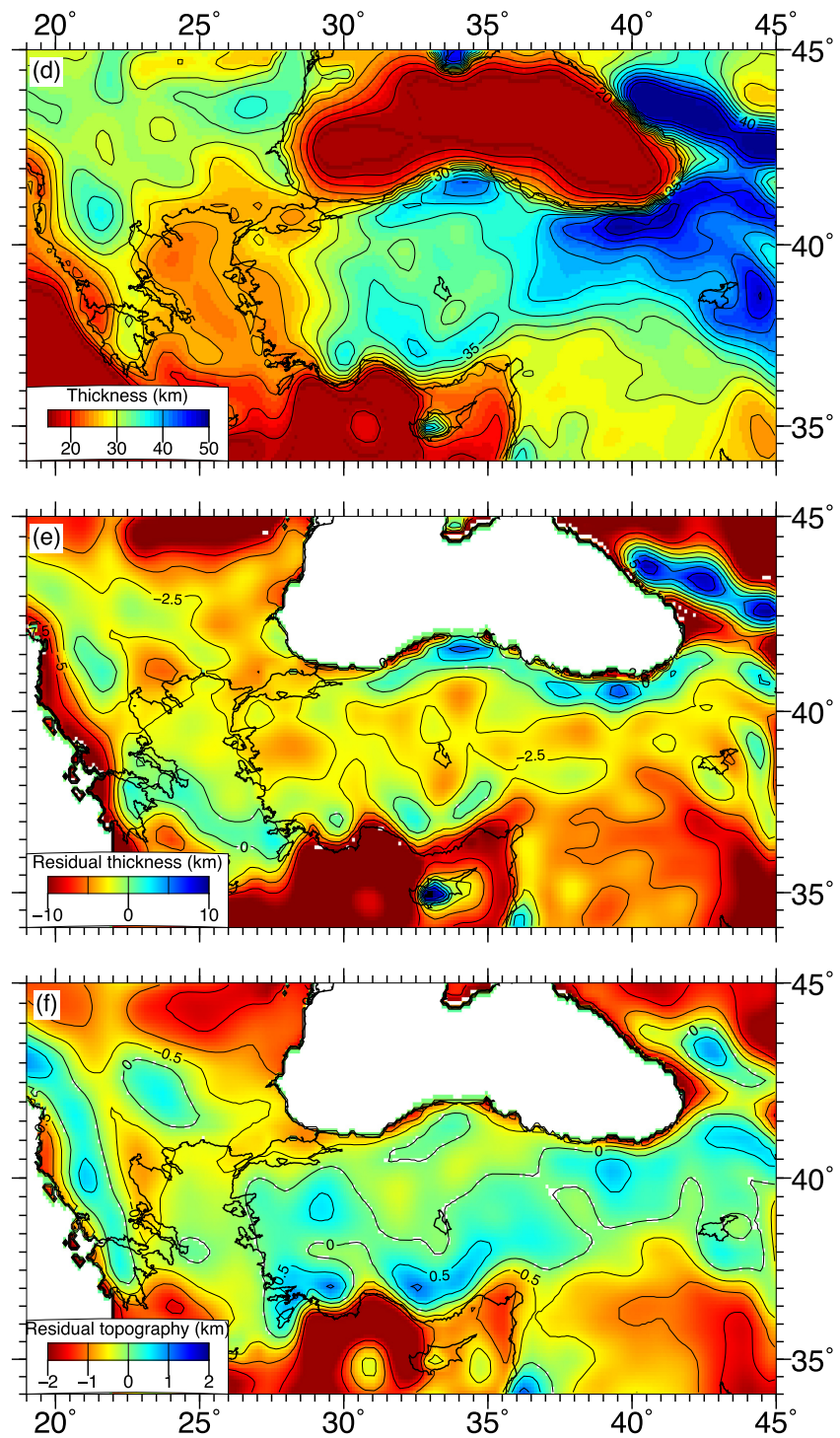

Figure 8. (a) Crustal thickness map estimated from topography with Airy-Heiskanen isostatic balance and a compensation depth of $45 \mathrm{~km}$. (b) Crustal thickness difference from the crustal model in Fig. 2(b). (c) Residual topography. (d) Crustal thickness map estimated from topography with Airy-Woollard isostatic balance and a compensation depth of $45 \mathrm{~km}$. (e) Crustal thickness difference from the crustal model in Fig. 2(b). (f) Residual topography. The white areas are clipped.

\subsection{Mantle density variations}

We constructed a 3-D density model for the upper mantle to $700 \mathrm{~km}$ depth using a $P$-wave velocity model estimated from teleseismic tomography (Aksarı 2018; Karabulut et al. 2018). Fig. 11(a) shows a cross-section along the $\mathrm{W}-\mathrm{E}$ profile $39.5^{\circ} \mathrm{N}$ in the velocity perturbation model with respect to AK135, while Fig. 11(b) displays our crustal thickness estimates and Bouguer anomaly along the same profile. The tomographic image is similar to the one presented by Biryol et al. (2011), but it extends to Eastern Anatolia and has better lateral and vertical resolution as it uses more data recorded by a denser seismic array. The velocity perturbations are scaled to density perturbations so that 1 per cent variation in velocity would correspond to $100 \mathrm{~kg} \mathrm{~m}^{-3}$ density perturbation. Various density perturbation models have been used for the mantle beneath AAD in previous publications that compute mantle density anomalies and induced mantle flow (Faccenna \& Becker 2010; Kaban et al. 2016). Kaban et al. (2016) computed density perturbations in the mantle between depths 50 and $350 \mathrm{~km}$ by joint inversion of gravity and residual topography data constrained by seismic tomography data. They found mantle density perturbations in the range $\pm 30 \mathrm{~kg} \mathrm{~m}^{-3}$ beneath AAD. Therefore, the scaling $\left(100 \mathrm{~kg} \mathrm{~m}^{-3} \delta \rho\right.$ for 1 per cent $\left.\delta V p / V p\right)$ selected here represents an upper bound. The computed gravity anomaly due to mantle heterogeneity along the $39.5^{\circ} \mathrm{N}$ profile is shown in Fig. 11c (in blue) and compared with the observed Bouguer anomaly (in red). Computed gravity values vary between $\pm 15 \mathrm{mGal}$ and they are $\sim 10$ times smaller than observed anomalies $( \pm 150 \mathrm{mGal})$. The strongest positive anomaly $(+5 \mathrm{mGal})$ is located above the subduction zone of 

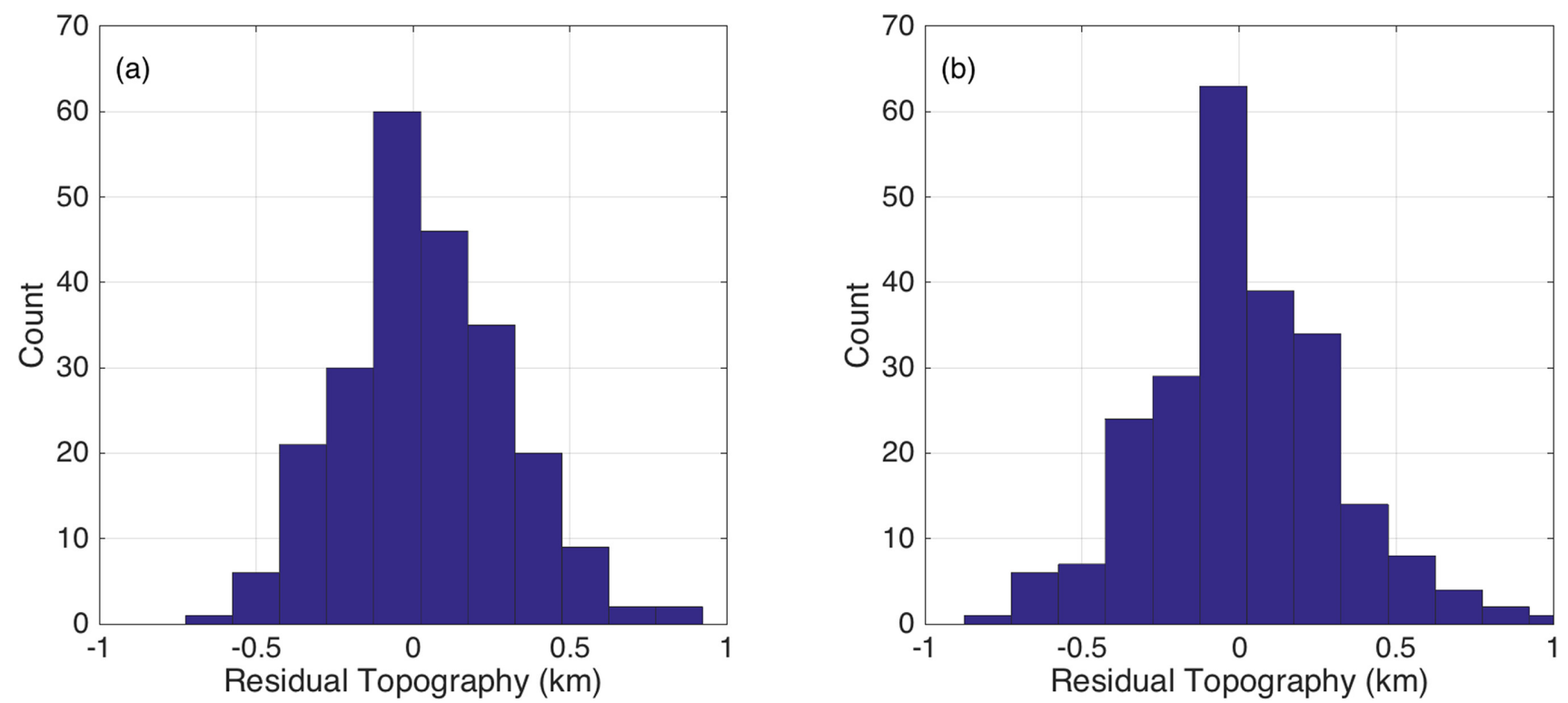

Figure 9. Distributions of residual topography sampled at station locations shown in Fig. 2 for: (a) Airy-Heiskanen model (Fig. 8c) and (b) Airy-Woollard model (Fig. 8f).
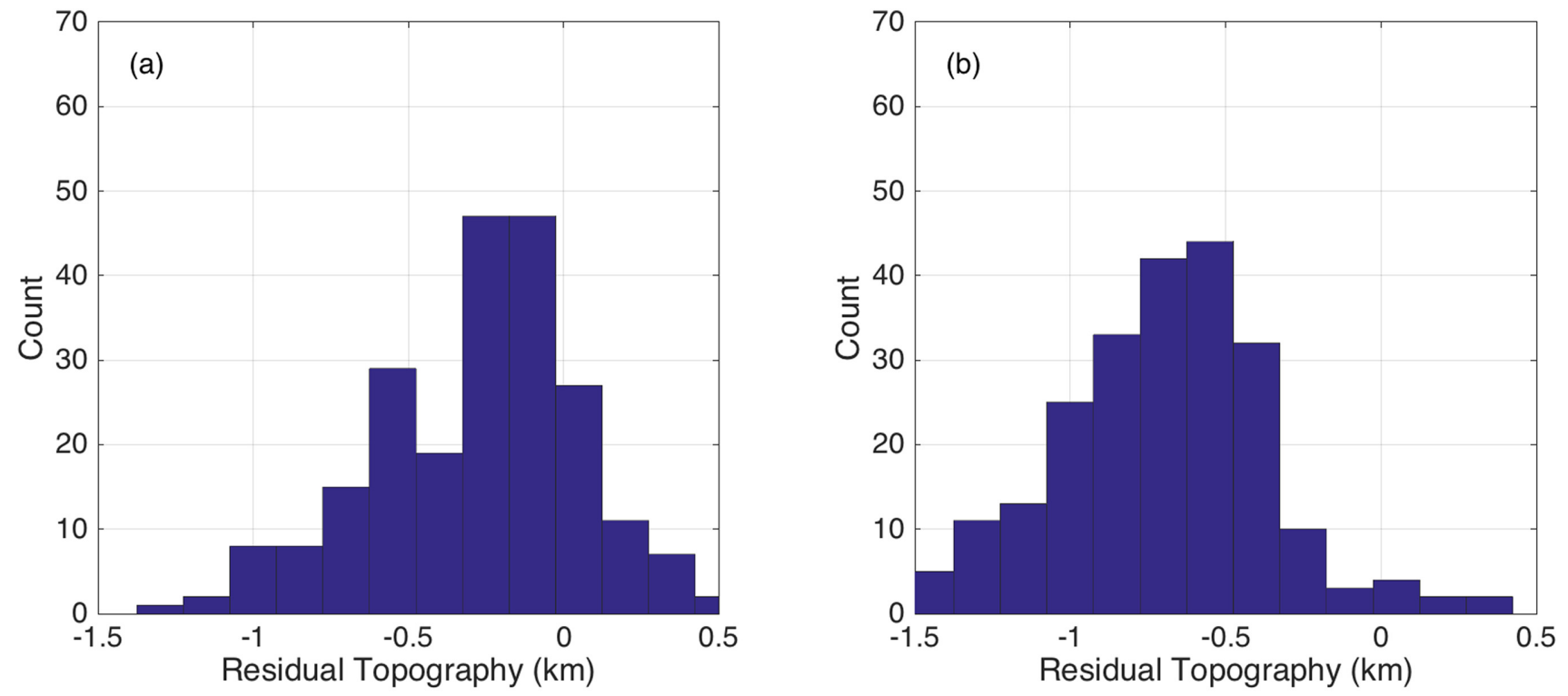

Figure 10. Distributions of residual topography computed for CRUST1.0 reference crustal model and a density difference between crust and mantle of: (a) $0.315 \times 10^{3} \mathrm{~kg} \mathrm{~m}^{-3}$ and (b) $0.450 \times 10^{3} \mathrm{~kg} \mathrm{~m}^{-3}$.

Western Greece while the strongest negative anomaly $(-15 \mathrm{mGal})$ is found above the low-velocity upper mantle of Eastern Anatolia. Fig. S7 shows the synthetic Bouguer anomaly map resulting from mantle density-velocity heterogeneities imaged by teleseismic tomography.

\section{DISCUSSION}

We aimed at providing new clues to decipher which processes contribute to building and supporting the topography of the Anatolian plateau, to smoothing crustal thickness changes, and to homogenizing the crustal structure of a belt constructed by accretion of continental blocks. We extensively used results of receiver function analysis, gravity modelling and Pn and teleseismic tomography to draw the following inferences.

\subsection{The state of isostasy in the AAD}

The topography and crustal thicknesses are well-correlated (Fig. 6). A nearly constant crustal density difference between crust and mantle is sufficient to explain the observed Bouguer anomaly with wavelengths of $100 \mathrm{~km}$ and longer. These two observations suggest that Airy-Heiskanen type isostasy prevails beneath AAD. Although isostasy holds for most of the domain, there are exceptions mainly along the northern and southern boundaries of Anatolia (Pontides and Taurides; Fig. 8). 


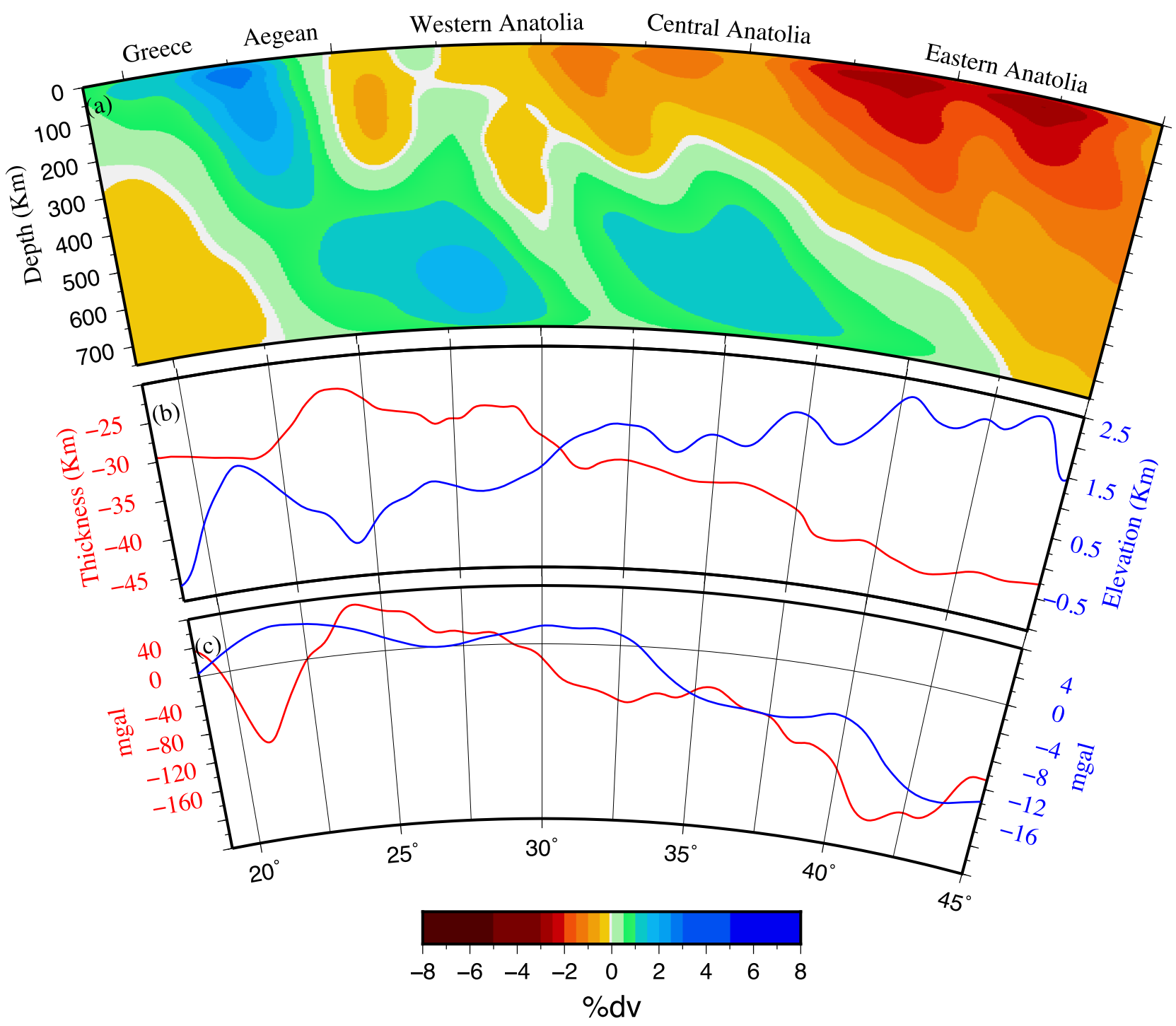

Figure 11. (a) W-E cross-section at $39.5^{\circ} \mathrm{N}$ in the $P$-wave teleseismic tomography model (Karabulut $e$ t al. 2018). Velocity perturbations are computed with respect to AK135 reference earth model. Colour scale in the bottom part of the figure. (b) Crustal thickness (red) and topography (blue) along $39.5^{\circ} \mathrm{N}$. (c) Observed Bouguer gravity anomaly along $39.5^{\circ} \mathrm{N}$ (red) and computed Bouguer gravity anomaly of the mantle (blue) using the velocity perturbation model in (a) converted to a density perturbation model. Note that the modelled gravity anomaly is 10 times smaller than the observed ones.

\subsection{The density structure}

The Anatolian crust does not show the significant seismic heterogeneities that might be expected from the initial tectonic buildup with amalgamation of different tectonic units. Smooth lateral changes in crustal thickness are detected by our CCP profiles (Fig. 3) that also document the lack of significant lateral heterogeneities within the crust as the main sutures between accreted blocks have no seismic signature in the CCP sections. This suggests that heating from the mantle may have played a strong part in the evolution of the overlying crust by smoothing out its original heterogeneous structure.

The fit of Bouguer anomaly to crustal thickness requires a low density contrast of $\sim 0.315 \times 10^{3} \mathrm{~kg} \mathrm{~m}^{-3}$ between crust and uppermost mantle over the whole $\mathrm{AAD}$, while the global average is $\sim 0.45 \times 10^{3} \mathrm{~kg} \mathrm{~m}^{-3}$ according to Zoback \& Mooney (2003). If the global average would be used, then the residual topography would be much larger.
An elevation change of $1 \mathrm{~km}$ is supported by $\sim 9.4 \mathrm{~km}$ of additional crustal thickness in Anatolia while it requires only $\sim 7 \mathrm{~km}$ of additional crustal thickness in Tibet (Le Pichon et al. 1992). This discrepancy is due to lower-than-average density contrast at Moho. As the crustal density in Anatolia is close to global average for continents $\left(\sim 2.85 \times 10^{3} \mathrm{~kg} \mathrm{~m}^{-3}\right.$ close to $2.83 \times 10^{3} \mathrm{~kg} \mathrm{~m}^{-3}$ estimated by Christensen $\&$ Mooney 1995), the lower-than-average density difference at Moho requires a lighter-than-average upper mantle. This inference is supported by seismic tomography results (Pn, surface wave and teleseismic) that display low $P$ and $S$ velocities in the upper mantle of the AAD.

\subsection{The mantle contribution}

Excess topography reaching $2 \mathrm{~km}$ on average in Eastern Anatolia is often interpreted as due to mantle buoyancy and/or radial traction due to mantle flow (dynamic topography). This interpretation 
is based on the observation that most of the Anatolian plateau is underlain by low-velocity, low-density upper mantle. In the absence of an accurate crustal model, the apparent correlation between topography and the low-velocity mantle structure is the main justification for the hypothesis of buoyant mantle and/or dynamic topography. We tested this hypothesis by computing Bouguer response of the mantle density anomalies (Fig. 11). Both the crustal thickness and topography overall follow the velocity-density perturbations: high topography and thick crust above low velocity-density mantle in Eastern Anatolia and low topography and thin crust above high velocity-density mantle in Western Anatolia. However, the contribution of the low velocity-low density mantle structure to the observed Bouguer gravity anomaly is small (Fig. 11c), precluding any significant effect of the anomalous mantle on the buoyancy of the crust. Nevertheless, we do not rule out the dynamic component altogether. The corner flow (poloidal component) between the asthenosphere and the mantle wedge and toroidal flow around slab edges should have an important contribution to the topography, particularly in the southern Aegean. In fact, the isostatic anomalies for the eastern Mediterranean calculated by Balmino et al. (2012) show local maxima in the Cretan Sea, in agreement with the corner flow component. However, Balmino et al. (2012)'s model shows $\sim 25 \mathrm{mGal}$ of isostatic anomaly spread over the Anatolian-Iranian plateau. Following the rule of thumb given in Molnar et al. (2015), we may expect that a dynamic component at the base of the lithosphere is responsible for the support of a few hundred meters of plateau elevation.

\subsection{Implications for the surface elevations}

East-west almost linear variations of topography and crustal thickness (Fig. 5) display striking similarities. Both increase with a constant gradient from the Aegean Sea to Eastern Anatolia. From west to east, the increase rates of crustal thickness and topography are $\sim 1$ and $\sim 0.1 \mathrm{~km} \mathrm{deg}^{-1}$, respectively, with almost a constant ratio of $\sim 9.4$ for E-W profiles across the Anatolian plateau. However the smoothness of the topography and crustal thickness profiles change with latitude. The northernmost and southernmost profiles are more affected by long-wavelength variations than the ones located in the plateau (Fig. 5). The profiles along Pontides $\left(40.5^{\circ} \mathrm{N}\right)$ and Taurides $\left(36.5^{\circ} \mathrm{N}\right)$ also display significant departures from constant gradient. Such constant gradients of Moho topology are also observed from receiver functions in the Tibetan plateau by Liu et al. (2014). By analogy with the Tibetan plateau, this observation lends support to the lower crustal flow hypothesis under Anatolia in terms of smoothing out irregularities of crustal thickness variations (Royden et al. 1997). Furthermore, this provides insights into thermo-mechanical weakening of the Anatolian plateau, especially for the region between the Pontides and the Taurides.

\subsection{The role of the GPE}

Constant gradients of topography and crustal thickness from the Aegean Sea to Eastern Anatolia not only suggest isostatic balance but also suggest that GPE (gravitational potential energy) differences may play an important part in shaping the landform (e.g. Özeren \& Holt 2010). Wavelengths greater than a few hundred km are absent in the topography and crustal thickness profiles within the Anatolian Plate in-between Pontides and Taurides. The linear character of the topography and crustal thickness changes with longitude breaks down along the northern and southern coasts of Anatolia while isostasy still holds (Fig. 5). In addition, the topography of the central Anatolian Plateau (between Pontides and Taurides) shows high elevations but low relief while Pontides and Taurides have higher elevations and large topography gradients towards the Black Sea and the Mediterranean Sea (see Fig. S8). We propose that the lithospheres of Pontides and Taurides are stronger than the lithosphere of intervening Anatolia and that the deformation of the weaker Anatolian Plate is channelized in-between the two strong blocks. The different lithospheric strengths of these three blocks would explain the observed differences in the east-west profiles of topography and crustal thickness (Fig. 5). The constant gradient observed for Anatolia might result from the lower viscosity of the lithosphere while the strong lithosphere of the other two domains would prevent such a linear behaviour.

\subsection{Thermal state of the crust}

The Curie Point depth (CPD), which is defined as the depth where magnetic minerals lose their magnetization $\left(\sim 580^{\circ} \mathrm{C}\right.$ isotherm, also referred to as the magnetic basement depth) gives direct clues on the thermal state of the crust. According to the map published by Aydin et al. (2005), the CPD is shallower than $20 \mathrm{~km}$ everywhere in Anatolia except along its northern and southern coasts while the global average is $22.4 \pm 5.5 \mathrm{~km}$ for continents (Li et al. 2017). It even rises to $\sim 10 \mathrm{~km}$ in Western Anatolia in the region of the grabens of the Menderes Massif. High heat flow may be the key factor for the homogenization of the Anatolian crust. The CPD map suggests that the lithosphere of Anatolia has a non-uniform thermal state and strength with a hot and weak lithosphere being confined in-between rheologically stronger blocks along its northern and southern boundaries. This north-south heterogeneity is confirmed by seismic tomography of the Anatolian crust and upper mantle that display high velocities in the Pontides and along the Hellenic-Cyprus subduction while widespread low velocities are observed in-between (Biryol et al. 2011; Salaün et al. 2012; Delph et al. 2015; Karabulut et al. 2015). We propose that the east-west GPE difference combines with the weak lower crust of Anatolia to contribute to the westward escape of Anatolia. East-west linear variations in topography and crustal thickness may also be explained by the weakness of the lower crust, which attenuates lateral changes.

\section{CONCLUSIONS}

Based on a new accurate crustal thickness model of the AAD and Bouguer anomaly modelling, we have shown that Airy-Heiskanen type isostasy prevails beneath most of the AAD. An anomalously low $\left(0.315 \times 10^{3} \mathrm{~kg} \mathrm{~m}^{-3}\right)$, spatially homogeneous density difference between crust and mantle is sufficient to explain the observed Bouguer anomaly with wavelengths of $100 \mathrm{~km}$ and longer. This low density contrast, $\sim 30$ per cent lower than the global average may be attributed to the thermal state of the uppermost mantle, in particular to its anomalously thin lithospheric lid imaged by seismic tomography. This hot buoyant upper mantle supports the high topographies of the Anatolian plateau, showing once more that isostasy is a simple but fundamental physical process in the evolution of lithosphere. 


\section{ACKNOWLEDGEMENTS}

We thank all the colleagues who helped with the SIMBAAD temporary seismic experiment. We thank the seismological agencies of Turkey (BU-KOERI; AFAD; TUBITAK-MRC) and Greece (NOA), for making the seismic data of their permanent networks available. Seismic instruments of the SIMBAAD experiment were provided by the SISMOB-RESIF national pool (France), and data are available from the RESIF datacentre (doi:10.15778/RESIF.YI2008; doi:10.15778/RESIF.1A2009; doi:10.15778/RESIF.XW2007). We thank Laurent Jolivet and an anonymous reviewer for their comments that helped to improve the manuscript significantly. Funding of project SIMBAAD was provided by Agence Nationale de la Recherche (France) under contract ANR-06-BLAN-0317. Maps were created using the Generic Mapping Tools (Wessel \& Smith 1991).

\section{REFERENCES}

Abgarmi, B., Delph, J.R., Özacar, A.A., Beck, S.L., Zandt, G., Sandvol, E, Türkelli, N. \& Biryol, C.B., 2017. Structure of the crust and African slab beneath the central Anatolian plateau from receiver functions: new insights on isostatic compensation and slab dynamics, Geosphere, 13, 1774-1787.

Aksar1, D., 2018. Determination of Upper Mantle Heterogeneities beneath Aegean-Anatolian Domain from Teleseismic Tomography, PhD thesis, Boğaziçi University, Turkey.

Allen, M., Jackson, J. \& Walker, R., 2004. Late Cenozoic reorganization of the Arabia-Eurasia collision and the comparison of short-term and long-term deformation rates, Tectonics, 23, TC2008.

Aydın, İ., Karat, H.İ. \& Koçak, A., 2005. Curie-point depth map of Turkey, Geophys. J. Int., 162, 633-640.

Bakırc1, T., Yoshizawa, K. \& Özer, M.F., 2012. Three-dimensional S-wave structure of the upper mantle beneath Turkey from surface wave tomography, Geophys. J. Int., 190, 1058-1076.

Balmino, G., Vales, N., Bonvalot, S. \& Briais, A., 2012. Spherical harmonic modeling to ultra-high degree of Bouguer and isostatic anomalies, $J$. Geod., 86, 499-520.

Barrier, E., Vrielynck, B., Bergerat, F., Brunet, M.-F., Mosar, J., Poisson, A. \& Sosson, M., 2008. MEBE Atlas of palaeotectonic maps of the Middle East, $C C G M$.

Bartol, J. \& Govers, R., 2014. A single cause for uplift of the Central and Eastern Anatolian plateau? Tectonophysics, 637, 116-136.

Bassin, C., Laske, G. \& Masters, G., 2000. The current limits of resolution for surface wave tomography in North America, EOS, Trans. Am. Geophys. Un., 81, F897.

Bijwaard, H. \& Spakman, W., 2000. Non-linear global P-wave tomography by iterated linearized inversion, Geophys J. Int., 141, 71-82.

Bijwaard, H., Spakman, W. \& Engdahl, E.R., 1998. Closing the gap between regional and global travel time tomography, J. geophys. Res., 103, 30055 30078 .

Birch, F., 1961. The velocity of compressional waves in rocks to 10 kilobars: 2, J. geophys. Res., 66, 2199-2224.

Biryol, C.B., Beck, S.L., Zandt, G. \& Ozacar, A.A., 2011. Segmented African lithosphere beneath the Anatolian region inferred from teleseismic P-wave tomography, Geophys J. Int., 184, 1037-1057.

Boschi, L., Faccenna, C. \& Becker, T.W., 2010. Mantle structure and dynamic topography in the Mediterranean Basin, Geophys Res. Lett., 37, L20303, doi:10.1029/2010GL045001.

Brun, J.P. \& Faccenna, C., 2008. Exhumation of high-pressure rocks driven by slab rollback, Earth planet. Sci. Lett., 272, 1-7.

Christensen, N.I. \& Mooney, W.D., 1995. Seismic velocity structure and composition of the continental crust: a global view, J. geophys. Res., 100, 9761-9788.

Chu, D., 2000. The globec kriging software package - easykrig 2.1, Technical report, Woods Hole Oceanographic Institution, ftp://globec.whoi.ed $\mathrm{u} / \mathrm{pub} / \mathrm{software} / \mathrm{kriging} /$ easy krig/.
Cosentino, D., Schildgen, T.F., Cipollari, P., Faranda, C., Gliozzi, E., Huda' ckova', N., Lucifora, S. \& Strecker, M., 2012. Late Miocene surface uplift of the southern margin of the central Anatolian Plateau, Central Taurides, Turkey, Geol Soc. Am. Bull., 124, 133-145.

Delph, J.R., Biryol, C.B., Beck, S.L., Zandt, G. \& Ward, K.M., 2015. Shear wave velocity structure of the Anatolian Plate: anomalously slow crust in southwestern Turkey, Geophys J. Int., 202, 261-276.

Dercourt, J. et al., 2000. M. Atlas Peri-Tethys, Palaeogeographical maps, 24 maps and explanatory notes, CCGM/CGMW.

Dewey, J.F., Hempton, M.R., Kidd, W.S.F., Şaroğlu, F. \& Şengör, A.M.C., 1986. Shortening of continental lithosphere: the neotectonics of Eastern Anatolia-a young collision zone, in Collisional Tectonics, Vol. 19, pp. 3-36, eds Coward, M.P. \& Ries, A.C., Geol Soc Sp.

Ercan, T., 1985. Orta Anadolu'daki Senozoyik volkanizması, Maden Tetkik ve Arama Dergisi, 107, 119-140.

Faccenna, C., Bellier, O., Martinod, J., Piromallo, C. \& Regard, V., 2006. Slab detachment beneath eastern Anatolia: a possible cause for the formation of the North Anatolian fault, Earth planet. Sci. Lett., 242, 85-97.

Faccenna, C. \& Becker, T., 2010. Shaping mobile belts by small-scale convection, Nature, 465, 602-605.

Fichtner, A., Saygin, E., Taymaz, T., Cupillard, P., Capdeville, Y. \& Trampert, J., 2013. The deep structure of the North Anatolian fault zone, Earth planet. Sci. Lett., 373, 109-117.

Fullea, J., Fernandez, M. \& Zeyen, H., 2008. FA2BOUG-A FORTRAN 90 code to compute Bouguer gravity anomalies from gridded free-air anomalies: Application to the Atlantic-Mediterranean transition zone, Comput. Geosci., 34, 1665-1681.

Gök, R., Mahdi, H., Al-Shukri, H. \& Rodgers, A.J., 2008. Crustal structure of Iraq from receiver functions and surface wave dispersion: Implications for understanding the deformation history of the Arabian- Eurasian collision, Geophys J. Int., 172, 1179-1187.

Göğüs, O.H. \& Pysklywec, R.N., 2008. Mantle lithosphere delamination driving plateau uplift and synconvergent extension in eastern Anatolia, Geology, 36, 723-726.

Hubert-Ferrari, A., van der Woerd, J., King, G., Villa, I. \& Armijo, R., 2007. New constraints on the Karlıova triple junction between Arabia, Eurasia and Anatolia, Geophys. Res. Abstr., 9, 06822.

Hubert-Ferrari, A., King, G., Woerd, J., Villa, I., Altunel, E. \& Armijo, R., 2009. Long-term evolution of the North Anatolian Fault: new constraints from its eastern termination, Geol. Soc. Sp., 311, 133-154.

Jolivet, L. \& Faccenna, C., 2000. Mediterranean extension and the AfricaEurasia collision, Tectonics, 19, 1095-1106.

Jolivet, L., Faccenna, C., Goes, B., Burov, E. \& Agard, P., 2003. Subduction tectonics and exhumation of high-pressure metamorphic rocks in the Mediterranean orogens, Am. J. Sci., 303, 353-409.

Jolivet, L. et al., 2013. Aegean tectonics: strain localisation, slab tearing and trench retreat, Tectonophysics, 597, 1-33.

Kaban, M.K., El Khrepy, S., Al-Arifi, N., Tesauro, M. \& Stolk, W. 2016. Three dimensional density model of the upper mantle in the Middle East: interaction of diverse tectonic processes, J. geophys. Res.: Solid Earth, 121(7), 5349-5364.

Karabulut, H., Paul, A., Afacan Ergün, T., Hatzfeld, D., Childs, D.M. \& Aktar, M., 2013. Long-wavelength undulations of the seismic Moho beneath the strongly stretched Western Anatolia, Geophys. J. Int., 194, 450-464.

Karabulut, H., Paul, A., Cambaz, D., Kömeç Mutlu, A., Aksari, D. \& Afacan Ergün, T., 2015. The images of Anatolia, in EGU General Assembly Conference Abstracts, Vol. 17, www.egu.2015.eu.

Karabulut, H., Aksarı, D., Paul, A. \& Özbakır, A., 2018. Upper mantle structure beneath the Anatolia-Aegean domain from high-resolution teleseismic tomography, in EGU General Assembly Conference Abstracts, Vol. 20, www.egu.2018.eu.

Kennett, B.L.N., Engdahl, E.R. \& Buland, R., 1995. Constraints on seismic velocities in the Earth from traveltimes, Geophys. J. Int., 122, 108-124.

Keskin, M., 2003. Magma generation by slab steepening and break off beneath a subduction-accretion complex: an alternative model for collisionrelated volcanism in eastern Anatolia, Turkey, Geophys Res. Lett., 30, 8046. 
Kind, R. et al., 2015. Thickness of the lithosphere beneath Turkey and surroundings from S-receiver functions, Solid Earth, 6, 971-984.

Komut, T., Gray, R., Pysklywec, R. \& Göğüş, O.H., 2012. Mantle flow uplift of western Anatolia and the Aegean: Interpretations from geophysical analyses and geodynamic modelling, J. geophys. Res., 117, B11412, doi:10.1029/2012JB009306.

Laske, G., Masters, G., Ma, Z. \& Pasyanos, M., 2013. Update on CRUST1.0 - a 1-degree Global Model of Earth's Crust, Geophys. Res. Abstracts, 15, Abstract EGU2013-2658.

Le Pichon, X., Fournier, M. \& Jolivet, L.,1992. Kinematics, topography, shortening and extrusion in the India-Eurasia collision, Tectonics, 11, 1085-1098.

Le Pichon, X., Lallemant, S.J., Chamot-Rooke, N., Lemeur, D. \& Pascal, G., 2002. The Mediterranean Ridge backstop and the Hellenic nappes, Mar. Geol., 186, 111-125.

Li, C-F., Lu, Y. \& Wang, J., 2017. A global reference model of Curie-point depths based on EMAG2, Sci. Rep., 7, 45129

Liu, Q.Y. et al., 2014. Eastward expansion of the Tibetan Plateau by crustal flow and strain partitioning across faults, Nat. Geosci., 7, 361-365.

Ludwig, W.J., Nafe, J.E. \& Drake, C.L., 1971. Seismic refraction, in The Sea, Vol. 4, pp. 53-84, ed. Maxwell, A.E., John Wiley \& Sons.

Mann, P. \& Taira, A., 2004. Global tectonic significance of the Solomon Islands and Ontong Java Plateau convergent zone, Tectonophysics, 389, 137-190.

McClusky, S. et al., 2000. Global Positioning System constraints on plate kinematics and dynamics in the eastern Mediterranean and Caucasus, $J$. geophys. Res., 105, 5695-5719.

McKenzie, D., 1972. Active tectonics of the Mediterranean region, Geophys. J. R. astr. Soc., 30, 109-185.

McKenzie, D., 1976. The East Anatolian Fault: a major structure in eastern Turkey, Earth planet. Sci. Lett., 29, 189-193.

Molnar, P., 1988. Continental tectonics in the aftermath of plate tectonics, Nature, 335, 131-137.

Molnar, P., England, P.C. \& Jones, C.H., 2015. Mantle dynamics, isostasy, and the support of high terrain, J. geophys Res., 120, 1932-1957.

Mutlu, A.K. \& Karabulut, H., 2011. Anisotropic Pn tomography of Turkey and adjacent regions, Geophys. J. Int., 187, 1743-1758.

Nafe, J.E. \& Drake, C.L., 1957. Variation with depth in shallow and deep water marine sediments of porosity, density and the velocities of compressional and shear waves, Geophysics, 22, 523-552.

Okay, A.I. \& Tüysüz, O. 1999. Tethyan sutures of northern Turkey, Geol. Soc., Lond., Spec. Publ., 156, 475-515.

Özbakır, A.D., Govers, R. \& Wortel, R., 2017. Active faults in the AnatolianAegean plate boundary region with Nubia, Turkish J. Earth Sci., 26, 3056.

Özeren, S.M. \& Holt, W.E., 2010. The dynamics of the eastern Mediterranean and eastern Turkey, Geophys. J. Int., 183, 1165-1184.

Pasquare, G., Poli, S., Vezzoli, L. \& Zanchi, A., 1988. Continental arc volcanism and tectonic setting in Central Anatolia, Turkey, Tectonophysics, 146, 217-230.

Paul, A., Karabulut, H., Kömeç-Mutlu, A. \& Salaün, G., 2014. A comprehensive and densely sampled map of shear-wave azimuthal anisotropy in the Aegean-Anatolia region, Earth planet. Sci. Lett., 389, 14-22.

Pavlis, N.K., Holmes, S.A., Kenyon, S.C. \& Factor, J.K., 2012. The development and evaluation of the Earth Gravitational Model 2008 (EGM2008), J. geophys Res., 117, B4, doi:10.1029/2011JB008916.

Piromallo, C. \& Morelli, A., 2003. P wave tomography of the mantle under the Alpine-Mediterranean area, J. geophys Res., 108, 2065.

Ranalli, G., 1995. Rheology of the Earth, 2nd edn, pp. XVI+414, Springer.

Reilinger, R. et al., 2006. GPS constraints on continental deformation in the Africa-Arabia-Eurasia continental collision zone and implications for the dynamics of plate interactions, J. geophys Res., 111, B5, doi:10.1029/2005JB004051.

Ring, U., Glodny, J., Will, T. \& Thomson, S., 2010. The Hellenic subduction system: high pressure metamorphism, exhumation, normal faulting, and large-scale extension, Annu. Rev. Earth Planet. Sci., 38, 45-76.
Romanyuk, T., Mooney, W.D. \& Detweiler, S., 2007. Two lithospheric profiles across southern California derived from gravity and seismic data, $J$. Geodyn., 43, 274-307.

Royden, L.H., Burchfiel, B.C., King, R.W., Wang, E., Chen, Z., Shen, F. \& Liu, Y., 1997. Surface deformation and lower crustal flow in eastern Tibet, Science, 276, 788-790.

Salaün, G. et al., 2012. High-resolution surface wave tomography beneath the Aegean-Anatolia region: constraints on upper-mantle structure, Geophys. J. Int., 190, 406-420.

Schildgen, T.F., Yıldırım, C., Cosentino, D. \& Strecker, M.R., 2014. Linking slab break-off, Hellenic trench retreat, and uplift of the Central and Eastern Anatolian plateaus, Earth-Sci. Rev., 128, 147-168.

Spakman, W., van der Lee, S. \& van der Hilst, R., 1993. Travel-time tomography of the European-Mediterranean mantle down to $1400 \mathrm{~km}$, Phys. Earth Planet. Int., 79, 3-74.

Starostenko, V. et al., 2004. Topography of the crust-mantle boundary beneath the Black Sea Basin, Tectonophysics, 381, 211-233.

Şaroğlu, F., 1985, Doğu Anadolu'nun Neotektonik Dönemde Jeolojik ve Yapısal Evrimi, pp. 94, PhD thesis, İstanbul Üniversitesi Fen Bilimleri Enstitüsü.

Şaroğlu, F., Emre, Ö. \& Kuşçu, I., 1992. The east Anatolian fault zone of turkey, Annales Tectonicae, Special Issue-Supplement to Volume VI, 99-125.

Şengör, A.M.C. \& Y1lmaz, Y., 1981. Tethyan evolution of Turkey: a plate tectonic approach, Tectonophysics, 75, 181-241.

Şengör, A.M.C., Özeren, S., Genç, T. \& Zor, E., 2003. East Anatolian high plateau as a mantle-supported, north-south shortened domal structure, Geophys Res. Lett., 30, 8045.

Şengör, A.M.C., Tüysüz, O., İmren, C., Sakınç, M., Eyidoğan, H., Görür, N., Le Pichon, X. \& Rangin, C., 2005. The North Anatolian Fault: A new look, Annu. Rev. Earth planet. Sci., 33, 37-112.

Şengör, A.C., Özeren, M.S., Keskin, M., Sakınç, M., Özbakır, A.D. \& Kayan, I., 2008. Eastern Turkish high plateau as a small Turkic-type orogen: Implications for post-collisional crust-forming processes in Turkic-type orogens, Earth-Sci. Rev., 90, 1-48.

Taghizadeh-Farahmand, F., Afsari, N. \& Sodoudi, F., 2015. Crustal thickness of Iran inferred from converted waves, Pure appl. Geophys., 172, 309331.

Tesauro, M., Kaban, M.K. \& Cloetingh, S.A., 2008. EuCRUST-07: A new reference model for the European crust, Geophys. Res. Lett., 35, L05313, doi:10.1029/2007GL032244.

Tenzer, R., Novák, P., Gladkikh, V. \& Vajda, P., 2012. Global crust-mantle density contrast estimated from EGM2008, DTM2008, CRUST2. 0, and ICE-5 G, Pure appl. Geophys., 169, 1663-1678.

Tezel, T., Shibutani, T. \& Kaypak, B., 2013. Crustal thickness of Turkey determined by receiver function, J. Asian Earth Sci., 75, 36-45.

Tirel, C., Gueydan, F., Tiberi, C. \& Brun, J.P., 2004 . Aegean crustal thickness inferred from gravity inversion. Geodynamical implications, Earth planet. Sci. Lett., 228, 267-280.

Toprak, V. \& Göncöoğlu, M.C., 1993. Tectonic control on the development of the Neogene-Quaternary Central Anatolian Volcanic Province, Turkey, Geol. J., 28, 357-369.

Vanacore, E.A., Taymaz, T. \& Saygin, E., 2013. Moho structure of the Anatolian Plate from receiver function analysis, Geophys. J. Int., 193, 329-337.

Vinnik, L.P., Erduran, M., Oreshin, S.I., Kosarev, G.L., Kutlu, Y.A., Çakir, Ö. \& Kiselev, S.G., 2014. Joint inversion of P-and S-receiver functions and dispersion curves of Rayleigh waves: the results for the Central Anatolian Plateau. Izvestiya, Phys. Solid Earth, 50, 622-631.

Wessel, P. \& Smith, W.H.F., 1991. Free software helps map and display data, EOS, Trans. Am. Geophys. Un., 72, 441.

Westaway, R., 1994. Present-day kinematics of the Middle East and eastern Mediterranean, J. geophys. Res., 99, 12071-12090.

Westaway, R., 2004. Kinematic consistency between the dead sea fault zone and the Neogene and Quaternary left-lateral faulting in SE Turkey, Tectonophysics, 391, 203-237. 
Wilcox, L.E., 1976. Airy-Woollard Isostasy, in The Geophysics of the Pacific Ocean Basin and its Margin, pp. 53-57, eds, Sutton G.H., Manghnani, M.H., Moberly, R. \& Mcafee, E.U., American Geophysical Union.

Woollard, G.P., 1962. The relation of gravity anomalies to surface elevation, crustal structure and geology (No. RR-62-9), Wisconsin University Madison Geophysical and Polar Research Center.

Woollard, G.P., 1970. Evaluation of the isostatic mechanism and the role of mineralogical transformations from seismic and gravity data, Phys. Earth Planet. Int., 3, 484-498.

Yegorova, T., Gobarenko, V. \& Yanovskaya, T., 2013. Lithosphere structure of the Black Sea from 3-D gravity analysis and seismic tomography, Geophys J. Int., 193, 287-303.

Zhu, L.P., 2000. Crustal structure across the San Andreas Fault, southern California from teleseismic converted waves, Earth planet. Sci. Lett., 179, 183-190.

Zhu, L. \& Kanamori, H., 2000. Moho depth variation in southern California from teleseismic receiver functions, J. geophys Res., 105, 2969-2980.

Zoback, M.L. \& Mooney, W.D., 2003. Lithospheric buoyancy and continental intraplate stresses, Int. Geol. Rev., 45, 95-118.

Zor, E., Sandvol, E., Gurbuz, C., Turkelli, N., Seber, D. \& Barazangi, M., 2003. The crustal structure of the East Anatolian plateau (Turkey) from receiver functions, Geophys Res. Lett., 30, 8044.

Nagy, D., 1966. The gravitational attraction of a right rectangular prism, Geophysics, 31, 362-371.

\section{SUPPORTING INFORMATION}

Supplementary data are available at GJI online.

Figure S1. Seismicity map of the Eastern Mediterranean region reported by EMSC in 1999-2013 (magnitude > 2.8). The colours indicate focal depths. Elevations greater than $800 \mathrm{~m}$ are shaded in gray using GTOPO-30 global topography data set. Bathymetry data are derived from GEBCO/97-BODC from the text and Sandwell and Smith (1997a, b).

Figure S2. Example of $H-k$ analysis of receiver function (RF) records at permanent station BLCB located on the Aegean coast $\left(38.3853^{\circ} \mathrm{N}, 27.042^{\circ} \mathrm{E}\right)$. Left-hand panel: radial $\mathrm{RF}$ plotted as a function of epicentral distance. Centre: radial RF plotted as a function of backazimuth. Right-hand panel: $H-k$ semblance plot and estimated values of crustal thickness and $V_{p} / V_{s}$ ratio.

Figure S3. A right rectangular prism in Cartesian coordinate system (Nagy 1966).

Figure S4. Pn velocity versus density using the linear relation $\rho=$ $\mathrm{a}+\mathrm{b} \mathrm{V}_{\mathrm{Pn}}$ (Romanyuk et al. 2007). The coefficients for the red line are taken from Ludwig et al. (1971) and the other three lines from Romanyuk et al. (2007).

Figure S5. (a) Pn velocity distribution from Mutlu \& Karabulut (2011). (b) Uppermost mantle density distribution computed from the Pn velocity distribution using the linear relation $\rho \mathrm{m}=0.7620+0.3185 \mathrm{~V}_{\mathrm{Pn}}$ (Ludwig et al. 1971).

Figure S6. Topography and residual topography estimates for CRUST1.0 crustal thickness model using two constant density differences at Moho.

Figure S7. Bouguer gravity anomaly computed for the 3-D mantle density model estimated from the teleseismic tomography model. Figure S8. 3-D views of the crustal thickness and topography.

Please note: Oxford University Press are not responsible for the content or functionality of any supporting materials supplied by the authors. Any queries (other than missing material) should be directed to the corresponding author for the paper. 